\title{
The photosynthesis - leaf nitrogen relationship at ambient and elevated atmospheric carbon dioxide: a meta-analysis
}

\section{Global Change Biology - IN PRESS}

Andrew G. Peterson', J. Timothy Ball', Yiqi Luo', Christopher B. Field², Peter B. Reich³, Peter S. Curtis', Kevin L. Griffin ${ }^{5}$, Carla A. Gunderson ${ }^{6}$, Richard J. Norby ${ }^{6}$, David T. Tissue ${ }^{7}$, Manfred Forstreuter ${ }^{8}$, Ana Rey9, Christoph S. Vogel ${ }^{10}$, and CMEAL participants ${ }^{11}$

${ }^{1}$ Biological Sciences Center, Desert Research Institute, PO Box 60220, Reno, NV, 89506, USA

${ }^{2}$ Carnegie Institution of Washington, Department of Plant Biology, 260 Panama Street, Stanford, CA 94305, USA

${ }^{3}$ Department of Forest Resources, University of Minnesota, St. Paul, MN, 55108, USA

${ }^{4}$ Department of Plant Biology, Ohio State University, 1735 Neil Ave., Columbus, OH 43210, USA

${ }^{5}$ Earth and Environmental Sciences, Lamont-Doherty Earth Observatory of Columbia University, 61 Route 9W, 6 Marine Biology, Palisades, NY 10964, USA

${ }^{6}$ Environmental Sciences Division, Oak Ridge National Laboratory, P.O. Box 2008, Oak Ridge, TN 37831, USA

${ }^{7}$ Department of Biology, Flint and Main Street, Texas Tech University, Lubbock, TX 79409, USA

${ }^{8}$ Technical University Berlin, Institute of Ecology, Koenigin-Luise-Str.22, D-14195 Berlin, Germany

${ }^{9}$ IERM, King's Buildings, Edinburgh University, Mayfield Road, Edinburgh, EH9 3JU, UK

${ }^{10}$ University of Michigan Biological Station, 9008 Biological Rd, Pellston MI, 49769, USA

${ }^{11} \mathrm{CMEAL}\left(\mathrm{CO}_{2}\right.$ Models/Experiments Activity for improved Links) is a collaborative project aimed at improving the representation of $\mathrm{CO}_{2}$ responses in ecosystem and global models. Participants are: Christopher B. Field (Carnegie Institution of Washington, Co-PI), J. Timothy Ball (Desert Research Institute, Co-PI), 
Jeffry S. Amthor (Lawrence Livermore National Laboratory), Bert Drake (Smithsonian Environmental Research Center), William R. Emanuel (University of Virginia), Dale W. Johnson (Desert Research Institute), Paul J. Hanson (Oak Ridge National Laboratory), Yiqi Luo (Desert Research Institute), Ross E. McMurtrie (University of New South Wales, Australia), Richard J. Norby (Oak Ridge National Laboratory), Walter C. Oechel (California State University, San Diego), Clenton E. Owensby (Kansas State University), William J. Parton (Colorado State University), Andrew G. Peterson (Desert Research Institute), Lars L. Pierce (California State University, Monterey Bay), Edward B. Rastetter (Marine Biological Laboratory), Anne Ruimy (Universite Paris-Sud), Steven W. Running (University of Montana), Donald R. Zak (University of Michigan).

Keywords: Photosynthesis, leaf nitrogen, carbon dioxide, meta-analysis

Corresponding Author: Andrew G. Peterson, Biological Sciences Center, Desert Research Institute, PO Box 60220, Reno, NV, 89506, USA.

Email: peterson@maxey.dri.edu

Fax: USA +702 6737485

Running Title: Photosynthesis leaf nitrogen and elevated $\mathrm{CO}_{2}$ 


\section{DISCLAIMER}

This report was prepared as an account of work sponsored by an agency of the United States Government. Neither the United States Government nor any agency thereof, nor any of their employees, make any warranty, express or implied, or assumes any legal liability or responsibility for the accuracy, completeness, or usefulness of any information, apparatus, product, or process disclosed, or represents that its use would not infringe privately owned rights. Reference herein to any specific commercial product, process, or service by trade name, trademark, manufacturer, or otherwise does not necessarily constitute or imply its endorsement, recommendation, or favoring by the United States Government or any agency thereof. The views and opinions of authors expressed herein do not necessarily state or reflect those of the United States Government or any agency thereof. 


\section{DISCLAIMER}

Portions of this document may be illegible in electronic image products. Images are produced from the best available original document. 


\section{Abstract}

Estimation of leaf photosynthetic rate $(A)$ from leaf nitrogen content $(N)$ is both conceptually and numerically important in models of plant, ecosystem, and biosphere responses to global change. The relationship between $\mathrm{A}$ and $\mathrm{N}$ has been studied extensively at ambient $\mathrm{CO}_{2}$ but much less at elevated $\mathrm{CO}_{2}$. This study was designed to (1) assess whether the A-N relationship was more similar for species within than between community and vegetation types, and (2) examine how growth at elevated $\mathrm{CO}_{2}$ affects the A-N relationship. Data were obtained for $39 \mathrm{C}_{3}$ species grown at ambient $\mathrm{CO}_{2}$ and $10 \mathrm{C}_{3}$ species grown at ambient and elevated $\mathrm{CO}_{2}$. A regression model was applied to each species as well as to species pooled within different community and vegetation types. Cluster analysis of the regression coefficients indicated that species measured at ambient $\mathrm{CO}_{2}$ did not separate into distinct groups matching community or vegetation type. Instead, most community and vegetation types shared the same general parameter space for regression coefficients. Growth at elevated $\mathrm{CO}_{2}$ increased photosynthetic nitrogen use efficiency for pines and deciduous trees. When species were pooled by vegetation type, the A-N relationship for deciduous trees expressed on a leaf-mass basis was not altered by elevated $\mathrm{CO}_{2}$, while the intercept increased for pines. When regression coefficients were averaged to give mean responses for different vegetation types, elevated $\mathrm{CO}_{2}$ increased the intercept and the slope for deciduous trees but increased only the intercept for pines. There were no statistical differences between the pines and deciduous trees for the effect of $\mathrm{CO}_{2}$. Generalizations about the effect of elevated $\mathrm{CO}_{2}$ on the A-N relationship, and differences between pines and deciduous trees will be enhanced as more data become available. 


\section{Introduction}

Photosynthesis is the essential energy harvesting process for the total biosphere (Lange et al., 1987) and therefore must be represented adequately in models of plant, ecosystem, and biosphere responses to global climate change. Both the light capture/electron transport and the carbon metabolism portions of photosynthesis require large investments of nitrogen in the form of proteins (Evans, 1989). The dependence of photosynthesis on nitrogenous compounds results in a general positive relationship between the lightsaturated photosynthetic rate (A) and leaf nitrogen content (N) (Field and Mooney, 1986; Walters and Field, 1987; Evans, 1989; Reich et al., 1994). This relationship, which is usually treated as linear, tends to be most clear when viewed across a broad range of species (e.g. Field and Mooney, 1986; Reich et al., 1991a) but can be highly variable when individual species or narrow species groupings are compared (Evans, 1989; Sinclair and Horie 1989; Reich et al., 1994; 1995). Despite this variation, the A-N relationship is an important component of predictive models of photosynthesis. It has been used as the conceptual (e.g. Woodward and Smith, 1994a,b) or numerical (e.g. Aber and Federer, 1992; Aber et al. 1996) basis for such models, and is related to the biochemical model of photosynthesis developed by Farquhar, von Caemmerer and Berry (1980) through the linear dependence of the maximum rate of carboxylation $\left(\mathrm{Vc}_{\max }\right)$ and the light-saturated rate of electron transport $\left(\mathrm{J}_{\max }\right)$ on leaf $\mathrm{N}$ (e.g. Harley et al. 1992; Kirschbaum et al. 1994).

The effect of elevated $\mathrm{CO}_{2}$ on photosynthesis varies across species and experimental conditions (e.g. Luo et al., 1994; Curtis, 1996). Nevertheless, long-term exposure to elevated $\mathrm{CO}_{2}$ has been shown to reduce levels of Rubisco messenger RNA and subsequent enzyme concentrations (Krapp et al., 1991; Stitt, 1991; Krapp et al., 1993; Tissue, et al., 1993), to alter the allocation of leaf $\mathrm{N}$ between Rubisco and electron transport components (Tissue et al. 1993), and to reduce the $\mathrm{N}$ concentration of leaf tissue (Luo et al., 1994; Curtis, 1996). While some of these effects of elevated $\mathrm{CO}_{2}$ may be regulated by nitrogen availability (McGuire et al., 1995), they all have the potential to alter the A-N relationship relative to ambient $\mathrm{CO}_{2}$. It is also possible that elevated $\mathrm{CO}_{2}$ may affect the $\mathrm{A}-\mathrm{N}$ relationship through interactions with other variables such as leaf mass per area. Some of these effects are represented in at least some ecosystem models, but none of 
the quantitative generalizations embodied in the models have been tested against data. This lack of empirical testing is a serious restriction for mechanistic models of ecosystem responses to global change (Kirschbaum, et al., 1994; Woodward, et al., 1995). In addition, our ability to generalize these effects of elevated $\mathrm{CO}_{2}$ across multiple species in a way that is relevant to such models is even more restricted.

This study was designed to ( 1 ) assess whether the A-N relationship is more similar for species within than between community and vegetation types, and (2) examine how elevated $\mathrm{CO}_{2}$ affects the A-N relationship. We used a combination of bivariate regression analysis and meta-analytic techniques to analyze the A-N relationship for $49 \mathrm{C}_{3}$ terrestrial plant species from field observations and field-based elevated $\mathrm{CO}_{2}$ experiments. 


\section{Methods}

Data

All data used in this analysis were obtained from measurements on plants growing in natural ecosystems, or from chamber-based elevated $\mathrm{CO}_{2}$ experiments conducted in the field. There were 39 species from field observations and 10 woody species (three pines and seven deciduous trees) from $\mathrm{CO}_{2}$ experiments (see Appendix for citations). Species were categorized by community type (e.g. successional, desert winter annuals, etc.) or by vegetation type (pines or deciduous trees). Community and vegetation types are referred to as groups for brevity. Data consisted of rates of net photosynthetic carbon assimilation $\left(\mathrm{A}_{\text {arrea, }} \mu \mathrm{mol}\left[\mathrm{CO}_{2}\right]\right.$ $\mathrm{m}^{-2}$ [leaf] $\mathrm{s}^{-1}$ ) measured at light saturation under growth conditions and operational levels of $\mathrm{C}_{i,}$ leaf nitrogen concentration $\left(\mathbb{N}_{\operatorname{mas}}, g[N] g^{-1}\right.$ [leaf]), and leaf mass per area (LMA, $g$ [leaf] $\mathrm{m}^{-2}$ [leaf]). From these variables we calculated photosynthesis per leaf mass $\left(\mathrm{A}_{\text {mass, }} \mu \mathrm{mol}\left[\mathrm{CO}_{2}\right] \mathrm{g}^{-1}\right.$ [leaf] $\left.\mathrm{s}^{-1}\right)$, and nitrogen per leaf area $\left(\mathrm{N}_{\text {mroos }}\right.$ $\mathrm{g}[\mathrm{N}] \mathrm{m}^{-2}$ [leaf]). In most data sets nitrogen concentration was determined using the same leaves that photosynthesis was measured on, although in some cases adjacent leaves were collected for $\mathrm{N}$ analysis. Causes of variation in leaf $\mathrm{N}$ differed across data sets and included fertilization treatments, sun vs. shade leaves, leaf developmental stage, and natural variation within leaf classes (see citations in Appendix for details). Photosynthesis measurements were made at ecologically relevant temperatures for each species (20 to $30^{\circ} \mathrm{C}$ depending on species), and measurements for single species were usually controlled to within $\pm 2^{\circ} \mathrm{C}$. Ambient $\mathrm{CO}_{2}$ concentration in the $\mathrm{CO}_{2}$ experiments was either 350 or $360 \mathrm{ppm}$ and the elevated concentration was either 650 or $700 \mathrm{ppm}$ (see citations in Appendix for details). 


\section{Linear regressions}

Leaf-level relationships between photosynthesis and leaf nitrogen content (both mass ( $A_{\text {mase }}$ vs. $\mathrm{N}_{\text {meas }}$ ) and area ( $A_{\text {aro }}$ vs. $\mathrm{N}_{\text {ares }}$ ) based) were determined using model I linear regression. The independent variables $\left(\mathrm{N}_{\operatorname{mass}}\right.$ and $\left.\mathrm{N}_{\text {arean }}\right)$ are random variables, but this does not present any problems with respect to linear regression as long as the frequency distribution of the independent variable is not a function of the regression coefficients (Neter et al., 1990, pp. 86). We assumed that this was the case for all data sets in addition to accepting the standard assumptions of general linear models (Neter et al., 1990, pp. 86 and 172). The basic assumptions of normality and homogeneity of variances were checked for all regressions using residual plots.

We present two different but complementary approaches to modeling the A-N relationship. In the first approach we fitted a single regression line to all data pooled together. This provides information on how photosynthesis changes across species with different leaf $\mathrm{N}$ contents and may be relevant to situations where changes in photosynthesis are driven by changes in species composition. We refer to this approach as the "pooled regression". Data were also pooled for each community and vegetation type to compare the A-N relationship across groups. The second approach used separate regressions for each species. The weighted average of each coefficient was calculated to give a mean and variance for each community and vegetation type. Weights were the inverse of each coefficient's variance, which is a function of the unexplained sum of squares and sample size. We refer to these averages as the "mean" or "averaged regressions", and they may be useful in situations where changes in photosynthesis are driven by changes in nitrogen availability for a particular community or vegetation type.

The linear model $Y_{i}=\beta_{0}+\beta_{1} X_{i 1}+\beta_{2} X_{i 2}+\beta_{3} X_{i 1} X_{i 2}+\varepsilon_{i}$ (Equation 1) was used to test for the effect of elevated $\mathrm{CO}_{2}$ on the A-N relationship. In this model $\beta_{0}$ is the centered $Y$ intercept for the ambient $\mathrm{CO}_{2}$ treatment. Centering involves subtracting the grand mean of the independent variable (i.e., the mean for

all species pooled together) from each data point, e.g. $\mathrm{N}_{\text {area } i}-\overline{\mathbf{N}}_{\text {ares }}$. This moves the $Y$ axis to the grand mean of the independent variable and eliminates any uncertainty in the value of the intercept that results from 
extrapolating beyond the range of the data (Ryan, 1997, pp. 129). Values for the intercept at $X=$ zero can be calculated by noting that $\overline{\mathrm{N}}_{\text {mass }}=0.017 \mathrm{~g} \mathrm{~g}^{-1}$ and $\overline{\mathrm{N}}_{\text {area }}=1.305 \mathrm{~g} \mathrm{~m}^{-2}$. $\beta_{1}$ in Equation 1 is the slope for the ambient $\mathrm{CO}_{2}$ treatment and $\beta_{2}$ is the change in the centered $Y$ intercept due to elevated $\mathrm{CO}_{2}$ (i.e., the intercept at elevated $\left.\mathrm{CO}_{2}=\beta_{0}+\beta_{2}\right) \cdot \beta_{3}$ (the interaction term) is the change in slope due to elevated $\mathrm{CO}_{2}$, and the actual slope at elevated $\mathrm{CO}_{2}=\beta_{1}+\beta_{3}$. $X_{\mathrm{in}}$ is the independent variable and $X_{\mathrm{i} 2}$ is a dummy variable coded as zero for ambient $\mathrm{CO}_{2}$ and one for elevated $\mathrm{CO}_{2}$ (Neter et al, 1990, pp. 356). This model was also used to test the robustness of the A-N relationship by comparing the relationship based on the data presented by Field and Mooney (1986) (the Vegetation In Natural Environments, or VINE data) with the relationship for all ambient $\mathrm{CO}_{2}$ data combined. The combined data included the VINE data, additional field data, and ambient $\mathrm{CO}_{2}$ treatment data from the $\mathrm{CO}_{2}$ experiments. This comparison was made by fitting the model to all data pooled together with the dummy variable coded as zero for the VINE data treated as a separate group, and one for all data combined. Weighted least squares regression was used for this analysis because the error variance was positively correlated with the independent variable (Neter et al., 1990, pp. 423).

\section{Generalizing the A-N relationship within and between community and vegetation types}

If regression coefficients were more similar within than between groups, then the accuracy of ecosystem and global models may be improved by incorporating specific details of different groups. We assessed the similarity of coefficients in two ways. First, we examined the distributional characteristics of the coefficients. This was done by treating each community and vegetation type as a separate population, and species within those groups were treated as random samples from those populations. Then for each group we compared the variance of the sample of coefficients to the variance expected if the population was normally distributed. If the observed and expected variances were similar then the sample was no more variable than would be expected from random sampling alone. On this basis we can classify the coefficients in that sample as being similar in magnitude. This was determined by calculating the ratio of the weighted sample-sum-of- 
squares and the sample variance $\left(\mathrm{s}^{2}\right)$ and comparing it to the $\chi^{2}$ distribution with $n$ - 1 degrees of freedom (Hedges and Olkin, 1985). A nonsignificant result suggests that the coefficients were similar (statistically homogeneous), otherwise they were dissimilar (statistically heterogeneous). Weights were the inverse of each coefficient's variance.

Second, we used nonparametric hierarchical cluster analysis (Sokal and Rohlf, 1981; Digby and Kempton, 1987) on the regression coefficients from ambient $\mathrm{CO}_{2}$ to gauge whether species within community and vegetation types formed discrete clusters. This would imply that the regression coefficients were more similar within than between groups. Coefficients were standardized to have a mean of zero and standard deviation of one, and the clustering criterion was complete linkage using Euclidean distances.

Statistical contrasts for the effect of elevated $\mathrm{CO}_{2}$ on pines vs. deciduous trees

For the pooled regressions, Equation 1 was used to compare the A-N relationship for pines with that for deciduous trees at each $\mathrm{CO}_{2}$ concentration. This was achieved by coding the dummy variable as zero for pines and one for deciduous trees.

For the mean regressions, the distribution of some of the coefficients from Equation 1 violated the assumptions of conventional parametric statistics (see results section for details). For this reason we used randomization tests (Manly, 1997) to compare the mean effect of elevated $\mathrm{CO}_{2}$ on the A-N relationship for the pines with that for the deciduous trees. All comparisons were based on 5000 randomizations testing the null hypothesis that the observed mean difference between groups was a chance effect of observations taken in a random order. Although much still needs to be learned about how randomization tests are affected by nonnormal and heteroscedastic data, these tests may be more powerful and robust than conventional parametric tests when data are less than ideal (Manly, 1997, pp. 80 and 98). 


\section{Results}

\section{The A-N relationship at ambient $\mathrm{CO}_{2}$}

Using the pooled regression for the VINE data expressed on a mass basis as a reference point, the additional ambient $\mathrm{CO}_{2}$ data compiled here increased the noncentered intercept slightly but did not affect the slope of the A-N relationship (Table 1 and Figure 1). This indicates that the mass based relationship is both general and robust when multiple species are pooled together (regression analyses for each individual species are presented in the Appendix). In contrast, when the area based relationship was considered, the additional ambient $\mathrm{CO}_{2}$ data did have a large effect on the VINE relationship. The additional data significantly reduced the noncentered intercept and significantly increased the slope (Table 1 and Figure 1).

The tests used to determine if species within groups had similar regression coefficients showed that species were dissimilar in all groups for the mass-based centered intercept at ambient $\mathrm{CO}_{2}$ (Table 2). Nevertheless, there was strong evidence that species had similar slopes for the mass-based relationship at ambient $\mathrm{CO}_{2}$ in each of the following groups: the deciduous trees and the pines from the $\mathrm{CO}_{2}$ experiments, the evergreen shrubs, the old field annuals, the secondary successionals from the Amazonian Tierra Firme forests, the Amazonian pioneer species, and to a lesser extent the Amazonian late successionals from the Tierra Firme forests (Table 2). Species in the remaining five community types were dissimilar for the slope of the massbased relationship at ambient $\mathrm{CO}_{2}$ (Table 2). For the area-based expression of the A-N relationship, species were similar for the slope but not for the intercept in the old field annuals, the pioneers, the secondary successionals and the pines (Table 2). Species in all other groups were dissimilar for both the slope and the intercept expressed on an area basis (Table 2).

Hierarchical cluster analysis of the mass-based regression coefficients at ambient $\mathrm{CO}_{2}$ did not separate species into discrete clusters matching the community or vegetation types presented in this study (hierarchical cluster trees not shown). Plotting the intercept coefficients against the slopes (Figure 2) shows little differentiation between groups. However, species in certain groups did appear to be clumped close 
together despite the lack of differentiation between groups (Figure 2), although this assessment may be considered somewhat subjective. Groups that appeared to cluster well were the old-field annuals, the secondary successionals, the late successionals, the deciduous trees and pines from the $\mathrm{CO}_{2}$ experiments, and the deciduous trees from field observations. Within each of these groups (except the deciduous trees from field observations), species also had similar slope coefficients (see above), which supports the notion that these community and vegetation types do form clusters even though they may not be distinct from other groups. Broadly similar patterns were observed for the area-based cluster analysis (Figure 2) although the scatter appeared to be greater than for the mass-based analysis. Overall, the results of the cluster analyses suggest that many groups shared the same general parameter space for regression coefficients. The averaged regression coefficients for the community and vegetation types that appeared to cluster well are presented in Table 3.

Effect of elevated $\mathrm{CO}_{2}$ on the $A-N$ relationship for pines and deciduous trees

Pooled regressions - the response based on pooling species together

The mass-based regressions on the pooled data for the pines, and the pooled data for the deciduous trees, suggest that the centered intercepts for both vegetation types were similar at ambient $\mathrm{CO}_{2}$ (Table 4 and Figure 3). The slope of the relationship at ambient $\mathrm{CO}_{2}$ was $59 \%$ higher for the deciduous trees than for the pines, however, this difference was not significant (Table 4). Growth at elevated $\mathrm{CO}_{2}$ appeared to increase the mass-based centered intercept for the deciduous trees but this was not significant (Table 4). Elevated $\mathrm{CO}_{2}$ did increase the centered intercept for the pines by $50 \%$, which was significant at a family-level confidence of $10 \%$. This apparent difference between vegetation types for the effect of elevated $\mathrm{CO}_{2}$ on the centered intercept was not significant (Table 4). Elevated $\mathrm{CO}_{2}$ did not appear to affect the slope of the mass-based A-N relationship for either vegetation type, and there was no detectable difference between vegetation types for this response (Table 4). 
The pooled regressions expressed on an area basis yielded a pattern of responses different from those discussed above. The centered intercept and slope for the deciduous trees at ambient $\mathrm{CO}_{2}$ were, respectively, $72 \%$ and $280 \%$ higher than for the pines at ambient $\mathrm{CO}_{2}$ (Table 4 and Figure 3). However, these differences were not significant due to the large variation in both $\mathrm{A}_{\text {area }}$ and $\mathrm{N}_{\text {aree }}$. Growth at elevated $\mathrm{CO}_{2}$ did not affect the centered intercept for the pines, but did increase the centered intercept for the deciduous trees by $46 \%$, which was significant at a family-level confidence of 5\% (Table 4). Again, this apparent difference between vegetation types was not significant (Table 4). There was no evidence of $\mathrm{a} \mathrm{CO}_{2}$ effect on the slope of the areabased A-N relationship for either the pines or the deciduous trees, and no evidence of any difference between vegetation types for this response (Table 4).

\section{Averaged regressions - the response based on averaging coefficients across species}

The averaged regressions expressed on a mass basis suggest that growth at elevated $\mathrm{CO}_{2}$ significantly increased the mean centered-intercept for both the pines $(66 \%)$ and the deciduous trees $(37 \%)$ at a family-level confidence of $10 \%$ (Table 5 and Figure 4). There was also evidence that elevated $\mathrm{CO}_{2}$ significantly increased the mean slope of the mass-based relationship for the deciduous trees (41\%), but not for the pines (Table 5). The randomization tests contrasting the means of each regression coefficient for the pines with those for the deciduous trees did not identify any significant differences between the two vegetation types at a family-level confidence of $10 \%$ (Table 5).

The averaged regressions expressed on an area basis indicate that growth at elevated $\mathrm{CO}_{2}$ significantly increased the mean centered-intercept for both the pines (46\%) and the deciduous trees (66\%) (Table 5 and Figure 4). Elevated $\mathrm{CO}_{2}$ also increased the mean slope of the area-based relationship by $87 \%$ for the deciduous trees, but had no significant effect on the mean slope for the pines (Table 5). Randomization tests did not identify any statistical differences between the pines and deciduous trees with regard to their area-based regression coefficients (Table 5).

The tests for similarity of regression coefficients suggest that species in both vegetation types were dissimilar for the effect of elevated $\mathrm{CO}_{2}$ on the centered intercept of the mass-based A-N relationship (Table 
2). Some of this variation within vegetation type may indicate species differences in the response of photosynthesis to elevated $\mathrm{CO}_{2}$ at a given leaf nitrogen content, although some of the variation may also be due to other factors such as the seasonal timing of data collection, the temperature at which measurements were made, or to differences among experiments in the $\mathrm{CO}_{2}$ concentration chosen for the elevated $\mathrm{CO}_{2}$ treatment (650 vs. $700 \mathrm{ppm}$ ). Nevertheless, species in both of these vegetation types were similar for the effect of elevated $\mathrm{CO}_{2}$ on the slope of the mass-based A-N relationship (Table 2). There was also strong evidence that the pines were similar for the effect of elevated $\mathrm{CO}_{2}$ on the area-based intercept and slope, but the deciduous trees appeared to be dissimilar for both of these coefficients (Table 2).

\section{General response to elevated $\mathrm{CO}_{2}$}

Because the comparisons of the pines and deciduous trees presented above did not identify any statistical differences between the two vegetation types, we combined both types into one group to generalize the effect of elevated $\mathrm{CO}_{2}$ on the A-N relationship. Using the combined data, the pooled regression expressed on a mass basis showed that growth at elevated $\mathrm{CO}_{2}$ significantly increased the centered intercept by $63 \%$, but did not affect the slope of the relationship (Table 4). The area-based pooled-regression showed a similar pattern - growth at elevated $\mathrm{CO}_{2}$ significantly increased the centered intercept by $48 \%$ and did not affect the slope (Table 4). The averaged regression for the mass-based expressions of $A$ and $N$ showed that elevated $\mathrm{CO}_{2}$ significantly increased both the centered intercept (42\%) and the slope (34\%) of the relationship (Table 5). This general pattern was also found for the area-based averaged-regression, where growth at elevated $\mathrm{CO}_{2}$ significantly increased the centered intercept by $59 \%$ and the slope by $74 \%$ (Table 5 ). The tests for homogeneity of the mass-based coefficients showed that the combined data were dissimilar for both intercept coefficients in Equation 1, but similar for both slope coefficients (Table 2). When these tests were performed on the combined data expressed on an area basis, all coefficients were dissimilar except the effect of elevated $\mathrm{CO}_{2}$ on the slope (Table 2). 


\section{Discussion}

\section{The $\mathrm{A}-\mathrm{N}$ relationship at ambient $\mathrm{CO}_{2}$}

This analysis showed that at ambient $\mathrm{CO}_{2}$ the mass-based A-N relationship assessed by pooling across multiple community and vegetation types was general and robust - $\mathrm{a}$ finding that is consistent with previous studies (e.g., Reich, et al., 1992; 1997). It is also clear from the rest of this analysis that plants do not simply move up and down the linear relationship in Figure 1 as nitrogen availability changes (see also Reich et al., 1995; 1998a) or as atmospheric $\mathrm{CO}_{2}$ concentration varies. Despite the strong positive correlation between photosynthesis and leaf $\mathrm{N}$ content viewed across many species, individual species do not always display an increase in photosynthesis with increasing leaf $\mathrm{N}$ content as the relationship in Figure 1 tends to suggest (see the Appendix for details). The data available to us indicate that the A-N relationship was highly variable across species, with more than an order of magnitude difference between certain species for the mass and area-based coefficients. Some of this variation in slope may be due to species differences in LMA because Reich et al. $(1994 ; 1997 ; 1998 \mathrm{a})$ have shown that for a given $\mathrm{N}_{\text {mass }}$ or range of $\mathrm{N}_{\text {mass, }}$ species with lower LMA have higher $A_{\operatorname{mas}}$ and a higher slope for the mass-based A-N relationship. Species specific differences in the proportional allocation of leaf nitrogen to photosynthetic and non-photosynthetic functions with increasing leaf nitrogen may also account for some of the variation in slope. Evans (1989) listed several possible explanations for variation in the intercept, including species specific differences in the total and relative allocation of leaf nitrogen to Rubisco and thylakoid proteins, differences in growth irradiance, and differences in stomatal conductance and consequently intercellular $\mathrm{CO}_{2}$ concentrations.

The nature of the relationship between leaf nitrogen content and photosynthesis changed as one moved up hierarchies from single species to multiple community and vegetation types. These changes may have important implications for predictive models of photosynthesis. For example, the slope of the massbased relationship pooled across all species (mean $\pm 95 \%$ c.i. $=9 \cdot 83 \pm 1 \cdot 16$ ) was greater than the weightedaverage slope for all species $(6 \cdot 26 \pm 0 \cdot 057)$. Why do these differences exist? One possible explanation 
involves changes in the relationship between LMA and leaf $N$ content, and between LMA and photosynthesis as additional species are pooled together. Variation in all three variables tends to be greater across species than within species (data not shown). Therefore the relationships between LMA, N, and photosynthesis may change as additional species are pooled together. Because of this, differences between the A-N relationship for the pooled regression versus the averaged regressions may be due, at least in part, to changes in the way that leaf $\mathrm{N}$ content and photosynthesis scale with LMA as additional species are pooled together (e.g. Reich et al. 1998a). If this is true, then differences in the A-N relationship between different hierarchical levels might be explained by simple changes in scaling relationships. Identifying these relationships could help us link the mechanisms of photosynthesis across different biological scales.

One aim of this study was to assess whether the A-N relationship was more similar for species within than between community and vegetation types. This information could be used to improve process-based biogeochemical models incorporating multiple species or communities. The cluster analyses and the distributional characteristics of the regression coefficients suggest that in approximately half the community and vegetation types represented here, species had similar A-N relationships. Thus, as a first approximation, the A-N relationship at ambient $\mathrm{CO}_{2}$ may be generalized for each of the following community and vegetation types: the deciduous trees and pines from the $\mathrm{CO}_{2}$ experiments, the old field annuals, the secondary successionals and late successionals from the Amazonian Tierra Firme forests, and the Amazonian pioneer species (see Table 3 for details). Even though the patterns of species groupings in this study were not distinct, Reich et al. (1995) present an example in which the A-N relationship pooled across species did discriminate clearly between deciduous hardwoods and evergreen conifers. Including additional variables such as LMA in analyses may help identify more robust and distinct groupings (e.g. Reich et al., 1998a).

The regression coefficients for the pines and deciduous trees measured at ambient $\mathrm{CO}_{2}$ in the $\mathrm{CO}_{2}$ experiments were substantially higher than values reported by Reich et al. (1995) for naturally-grown adult deciduous hardwoods and evergreen conifers (comparisons not shown). In addition, our comparisons of the pines and deciduous trees from the $\mathrm{CO}_{2}$ experiments did not identify any differences between these vegetation types at either ambient or elevated $\mathrm{CO}_{2}$, whereas Reich et al. (1995) found distinctly different A-N responses 
for deciduous hardwoods and conifers at ambient $\mathrm{CO}_{2}$. Part of the difference between the regressions reported here and those of Reich et al. (1995) may be due to different species combinations. For instance, both Populus euramericana and the nitrogen fixer Alnus glutinosa in the current data set have a large effect on the overall slope for the deciduous trees in the $\mathrm{CO}_{2}$ experiments. Removing these species from the current study would tend to reduce the slope of the relationship, making it more similar to that of Reich et al. (1995). Additional variation may also be due to the age of the plants because trees in the $\mathrm{CO}_{2}$ experiments were quite young and Reich et al. (1998b) found that the slope of the A-N relationship was typically higher for younger than for older trees.

Perhaps more importantly, the differences discussed above may reflect effects of experimental manipulations. In the natural environment, photosynthesis and the A-N relationship interact with, and are constrained by, multiple environmental variables (e.g. Field et al., 1983; Fredeen, et al., 1991). Many $\mathrm{CO}_{2}$ chamber experiments are designed to examine a single variable (e.g. water or nitrogen) interacting with $\mathrm{CO}_{2}$ while other potential resource limitations are either minimized or eliminated. These differences between the $\mathrm{CO}_{2}$ chamber experiments and the natural A-N relationship suggest a need for multi-factorial experiments to assist the development of predictive models.

\section{The $\mathrm{A}-\mathrm{N}$ relationship at elevated $\mathrm{CO}_{2}$}

Growth at elevated $\mathrm{CO}_{2}$ significantly increased photosynthetic nitrogen use efficiency for the pines and deciduous trees, but the nature of this effect depended on how the A-N relationship was modeled. For the pooled regressions, which show how photosynthesis changed across species with different leaf $\mathrm{N}$ content, the regression line for the elevated $\mathrm{CO}_{2}$ data was offset vertically from the line for the ambient $\mathrm{CO}_{2}$ data without affecting the slope. At a cursory level, this may be interpreted as meaning that the response of photosynthesis to elevated $\mathrm{CO}_{2}$ may be predicted by simply extrapolating vertically from the ambient $\mathrm{CO}_{2}$ line to the elevated $\mathrm{CO}_{2}$ line. This would give the expected photosynthesis at elevated $\mathrm{CO}_{2}$ for a given leaf $\mathrm{N}$. However, elevated $\mathrm{CO}_{2}$ also tends to decrease $\mathrm{N}_{\text {mass }}$ and increase $\mathrm{N}_{\text {area }}$ (Luo et al., 1994; Curtis, 1996), so these adjustments need be taken into account to accurately predict the response for a particular species. 
When the regression coefficients were averaged to give a mean and variance for each vegetation type, elevated $\mathrm{CO}_{2}$ increased the centered intercept for the pines and deciduous trees, and increased the slope for the deciduous trees but not the pines. This difference between the pines and deciduous trees, while not statistically significant, may reflect larger interactions between $\mathrm{CO}_{2}$ and $\mathrm{LMA}$ for the deciduous trees than for the pines. The extent to which LMA was responsible for the differences between the pooled and averaged regressions is not clear, but as discussed earlier, it may prove to be an important variable. Nevertheless, the observed differences between the pines and deciduous trees may be large enough to yield important differences in biogeochemical and biogeographic models. Sensitivity analyses exploring these potential differences are needed.

The two approaches used to model the A-N relationship (pooled and averaged regressions) produced different functional forms of the relationship. The choice of which approach to use in biogeochemical and biogeographic models depends on the questions being addressed, and the temporal and spatial scales being modeled. Use of the pooled regressions may be most appropriate when individual species are not the focus of interest. Such modeling scenarios may involve large spatial or temporal scales at which changes in photosynthesis are driven more by changes in dominant species composition than by changes in leaf $\mathrm{N}$ content of a single species. For example, a change in photosynthesis associated with a successional change in species could be modeled using the pooled regression presented in this paper. Regressions based on the averaged coefficients for a particular community or vegetation type may provide greater accuracy for modeling the response of photosynthesis over spatial or temporal scales at which species composition is not expected to change. For example, changes in photosynthesis for a mixed deciduous forest in response to changes in nitrogen availability could be simulated over periods of 50 to 100 years using the averaged regression for deciduous trees presented in this paper. This approach gives the typical relationship between photosynthesis and leaf $\mathrm{N}$ for a particular mixture of species, along with a measure of the variation in that relationship. There is clearly a need to determine how sensitive models are to these different representations of the A-N relationship. A judicious application of both approaches may provide a functionally important mechanism for adding realism to the competitive asymmetries among plants of different growth forms and from different biomes. 


\section{Acknowledgments}

We thank three anonymous reviewers for insightful and constructive comments on an earlier version of this manuscript. This synthesis was supported by the US Department of Energy, grant number DE-FG0295ER62084 to the CMEAL program. The Electric Power Research Institute (EPRD) provided support for CMEAL meetings. Belinda Medlyn played an invaluable role in negotiating collaboration with members of the European Collaboration On $\mathrm{CO}_{2}$ Responses Applied to Forests and Trees (ECOCRAFT) program. Support for the initial organization of CMEAL was provided by the Desert Research Institute. CMEAL is a core project of the GCTE (Global Change and Terrestrial Ecosystems) program. 


\section{References}

Aber JD, Federer CA (1992) A generalized, lumped-parameter model of photosynthesis, evapotranspiration and net primary production in temperate and boreal forest ecosystems. Oecologia 92 463-474.

Aber JD, Reich PB, Goulden ML (1996) Extrapolating leaf $\mathrm{CO}_{2}$ exchange to the canopy: a generalized model of forest photosynthesis compared with measurements by eddy correlation. Oecologia 106 257-265.

Curtis PS (1996) A meta-analysis of leaf gas exchange and nitrogen in trees grown under elevated carbon dioxide. Plant, Cell and Environment 19 127-137.

Curtis PS, Vogel CS, Pregitzer KS, Zak DR, Teeri JA (1995) Interacting effects of soil fertility and atmospheric $\mathrm{CO}_{2}$ on leaf area growth and carbon gain physiology in Populus X euramericana (Dode) Guinier. New Phytologist 129 253-263.

Digby PGN, Kempton RA (1987) Multivariate Analysis of Ecological Communities. Chapman and Hall, London, $206 \mathrm{pp}$.

Evans JR (1989) Photosynthesis and nitrogen relationships in leaves of $C_{3}$ plants. Oecologia 78 9-19.

Farquhar GD, von Caemmerer S, Berry JA (1980) A biochemical model of photosynthetic $\mathrm{CO}_{2}$ assimilation in leaves of $C_{3}$ species. Planta 149 78-90.

Field C, Merino J, Mooney HA (1983) Compromises between water-use efficiency and nitrogen-use efficiency in five species of California evergreens. Oecologia (Berlin) 60 384-389.

Field C, Mooney HA (1986) The photosynthesis-nitrogen relationship in wild plants. In: On the Economy of Plant Form and Function (ed Givnish TJ), pp. 25-55. Cambridge University Press, Cambridge. 
$09 / 25 / 98$

Peterson et al.

Forstreuter M (1995) Bestandesstruktur und Netto-Photosynthese von jungen Buchen (Fagus sylvatica L.) unter erhöhter $\mathrm{CO}_{2}$-Konzentration. Verhandlungen der Gesellschaft für Okologie (Frankfurt) Band 24 283292.

Fredeen AL, Gamon JA, Field CB (1991) Responses of photosynthesis and carbohydrate-partitioning to limitations in nitrogen and water availability in field-grown sunflower. Plant, Cell and Environment 14963970.

Gunderson CA, Wullschleger SD (1994) Photosynthetic acclimation of forest trees to a doubling of atmospheric $\mathrm{CO}_{2}$ : a broader perspective. Photosynthesis Research 39 369-388.

Harley PC, Thomas RB, Reynolds JF, Strain BR (1992) Modelling photosynthesis of cotton grown in elevated $\mathrm{CO}_{2}$. Plant, Cell and Environment 15 271-282.

Hedges LV, Olkin I (1985) Statistical Methods for Meta-Analysis. Academic Press, Orlando, 369 pp.

Kirschbaum MUF, King DA, Comins $\mathrm{HN}$, et al. (1994) Modelling forest response to increasing $\mathrm{CO}_{2}$ concentration under nutrient-limited conditions. Plant, Cell and Environment 17 1081-1099.

Krapp A, Hofmann B, Schafer C, Stitt M (1983) Regulation of the expression of rcbS and other photosynthetic genes by carbohydrate: a mechanism for the 'sink regulation' of photosynthesis? Plant Journal $3817-828$.

Krapp A, Quick WP, Stitt M (1991) Ribulose-1,5-bisphosphate carboxylase-oxygenase, other photosynthetic enzymes and chlorophyll decrease when glucose is supplied to mature spinach leaves via the transpiration stream. Planta $18658-69$. 
Lange OL, Beyschlag W, Tenhunen JD (1987) Control of leaf carbon assimilation - input of chemical energy into ecosystems. In: Potentials and Limitations of Ecosystem Analysis (eds. Schulze E-D, Zwölfer H), pp. 149-163. Ecological Studies 61. Springer, Berlin, Heidelberg, New York.

Luo Y, Field CB, Mooney HA (1994) Predicting responses of photosynthesis and root fraction to elevated $\left[\mathrm{CO}_{2}\right] \mathrm{a}$ : interactions among carbon, nitrogen, and growth. Plant Cell and Environment 17 1195-1204.

Manly BFJ (1997) Randomization, Bootstrap and Monte Carlo Methods in Biology. Chapman and Hall, London, $399 \mathrm{pp}$.

McGuire AD, Mellilo JM, Joyce LA (1995) The role of nitrogen in the response of forest net primary production to elevated atmospheric carbon dioxide. Annual Review of Ecology and Systematics 26 473-503.

Neter J, Wasserman W, Kutner MH (1990) Applied Linear Statistical Models. Irwin, Illinois, 1181 pp.

Norby RJ, Edwards NT, Riggs JS, Abner CH, Wullschleger SD, Gunderson CA (1997) Temperaturecontrolled open-top chambers for global change research. Global Change Biology 3 259-267.

Reich PB, Ellsworth DS, Walters MB (1998a) Specific leaf area regulates photosynthesis-nitrogen relations: global evidence from within and across species and functional groups. Functional Ecology (in press).

Reich PB, Kloeppel BD, Ellsworth DS, Walters MB (1995) Different photosynthesis-nitrogen relations in deciduous hardwood and evergreen coniferous tree species. Oecologia 104 24-30.

Reich PB, Uhl C, Walters MB, Ellsworth DS (1991a) Leaf life-span as a determinant of leaf structure and function among 23 tree species in Amazonian forest communities. Oecologia 86 16-24.

Reich PB, Walters MB (1994) Photosynthesis-nitrogen relations in Amazonian tree species. II. Variation in nitrogen vis-à-vis specific leaf area influences mass- and area-based expressions. Oecologia 97 73-81. 
Reich PB, Walters MB, Ellsworth DS (1991b) Leaf age and season influence the relationships between leaf nitrogen, leaf mass per area and photosynthesis in maple and oak trees. Plant, Cell and Environment $14251-$ 259.

Reich PB, Walters MB, Ellsworth DS (1992) Leaf life-span in relation to leaf, plant and stand characteristics among diverse ecosystems. Ecological Monographs 62 365-392.

Reich PB, Walters MB, Ellsworth DS (1997) From tropics to tundra: Global convergence in plant functioning. Proceedings of the National Academy of Science 94 13730-13734.

Reich PB, Walters MB, Ellsworth DS, Uhl C (1994) Photosynthesis-nitrogen relations in Amazonian tree species. I. Patterns among species and communities. Oecologia 97 62-72.

Reich PB, Walters MB, Tjoelker MG, Vanderklein D, Buschena C (1998b) Photosynthesis and respiration rates depend on leaf and root morphology and nitrogen concentration in nine boreal tree species differing in relative growth rate. Functional Ecology (in press).

Rey A, Jarvis PG (1998) Long term photosynthetic acclimation to increased atmospheric $\mathrm{CO}_{2}$ concentration in young birch trees (Betula pendula Roth.). Tree Physiology (in press).

Ryan TP (1997) Modern Regression Methods. Wiley \& Sons, New York, 515 pp.

Sinclair TR, Horie T (1989) Leaf nitrogen, photosynthesis, and crop radiation use efficiency: a review. Crop Science 29 90-98.

Sokal RR, Rohlf FJ (1981) Biometry. Freeman, New York, 859 pp.

Stitt M (1991) Rising $\mathrm{CO}_{2}$ levels and their potential significance for carbon flow in photosynthetic cells. Plant, Cell and Environment 14 741-762. 
Tissue DT, Griffin KL, Ball JT (in review.) Photosynthetic adjustment in field grown Ponderosa pine trees after six years exposure to elevated $\mathrm{CO}_{2}$. Tree Physiology.

Tissue DT, Thomas RB, Strain BR (1993) Long-term effects of elevated $\mathrm{CO}_{2}$ and nutrients on photosynthesis and Rubisco in loblolly pine seedlings. Plant, Cell and Environment 16 859-865.

Tissue DT, Thomas RB, Strain BR (1997) Atmospheric $\mathrm{CO}_{2}$ enrichment increases growth and photosynthesis of Pinus taeda: a 4 year experiment in the field. Plant, Cell and Environment 20 1123-1134.

Vogel CS, Curtis PS (1995) Leaf gas exchange and nitrogen dynamics of N fixing, field-grown Alnus glutinosa under elevated atmospheric $\mathrm{CO}_{2}$. Global Change Biology 1 55-61.

Walters MB, Field CB (1987) Photosynthetic light acclimation in two rain forest Piper species with different ecological amplitudes. Oecologia 72 449-459.

Whitehead D, Hogan KP, Rogers GND, et al. (1995) Performance of large open-top chambers for long-term field investigations of tree response to elevated carbon dioxide concentration. Journal of Biogeography 22 307-313.

Woodward FI, Smith TM (1994a) Predictions and measurements of the maximum photosynthetic rate, $A_{\operatorname{mex}}$ at the global scale. In: Ecophysiology of Photosynthesis (eds. Schulze E-D, Caldwell MM), pp. 491-509. Springer, Berlin, Heidelberg, New York.

Woodward FI, Smith TM (1994b) Global photosynthesis and stomatal conductance: Modelling the controls by soil and climate. Advances in Botanical Research $201-41$.

Woodward FI, Smith TM, Emanuel WR (1995) A global land primary productivity and phytogeography model. Global Biogeochemical Cycles 9 471-490. 


\section{Tables}

Table 1. Pooled regression coefficients comparing the A-N relationship for the VINE data with that for the VINE data plus all additional ambient $\mathrm{CO}_{2}$ data. Values are lower $95 \%$ c.i. < estimate < upper $95 \%$ c.i. Note: intercepts were not centered for this comparison.

\begin{tabular}{|c|c|c|c|c|}
\hline Expression & VINE intercept & VINE slope & $\begin{array}{c}\text { Effect of additional } \\
\text { data on VINE intercept }\end{array}$ & $\begin{array}{c}\text { Effect of additional } \\
\text { data on VINE slope }\end{array}$ \\
\hline Mass & $\begin{array}{c}-0.07<-0.06<-0.04 \\
\mu \mathrm{mol} \mathrm{g} \mathrm{g}^{-1}\end{array}$ & $\begin{array}{c}8.67<9.83<11.00 \\
\mu \mathrm{mol} \mathrm{g} \mathrm{s}^{-1} \mathrm{~s}^{-1}\end{array}$ & $\begin{array}{c}0.002<0.02<0.04 \\
\mu \mathrm{mol} \mathrm{g} \mathrm{g}^{-1}\end{array}$ & $\begin{array}{c}-2.42<-1.18<0.07 \\
\mu \mathrm{mol} \mathrm{g} \mathrm{s}^{-1}\end{array}$ \\
\hline Area & $\begin{array}{c}3.24<4.78<6.32 \\
\mu \mathrm{mol} \mathrm{m} \mathrm{s}^{-2} \mathrm{~s}^{-1}\end{array}$ & $\begin{array}{c}2.34<3.43<4.51 \\
\mu \mathrm{mol} \mathrm{g} \mathrm{s}^{-1}\end{array}$ & $\begin{array}{c}-6.35<-4.73<-3.10 \\
\mu \mathrm{mol} \mathrm{m} \mathrm{m}^{-1} \mathrm{~s}^{-1}\end{array}$ & $\begin{array}{c}1.31<2.50<3.70 \\
\mu \mathrm{mol} \mathrm{g} \mathrm{g}^{-1}\end{array}$ \\
\hline
\end{tabular}


Table 2. Chi-square $P$ values for tests of similarity of regression coefficients within community and vegetation types. A nonsignificant value suggests similarity.

\begin{tabular}{|c|c|c|c|c|c|c|c|c|c|c|}
\hline \multirow[t]{2}{*}{ Design } & \multirow[t]{2}{*}{ Community or vegetation type } & \multirow[t]{2}{*}{$\mathbf{N}$} & \multicolumn{4}{|c|}{ Mass based expression } & \multicolumn{4}{|c|}{ Area based expression } \\
\hline & & & $\begin{array}{c}\text { Centered } \\
\text { intercept at } \\
\text { ambient } \mathrm{CO}_{2}\end{array}$ & $\begin{array}{c}\text { Slope at } \\
\text { ambient } \mathrm{CO}_{2}\end{array}$ & $\begin{array}{c}\text { Effect of } \\
\text { elevated } \mathrm{CO}_{2} \\
\text { on centered } \\
\text { intercept }\end{array}$ & $\begin{array}{l}\text { Effect of } \\
\text { elevated } \mathrm{CO}_{2} \\
\text { on slope }\end{array}$ & $\begin{array}{c}\text { Centered } \\
\text { intercept at } \\
\text { ambient } \mathrm{CO}_{2}\end{array}$ & $\begin{array}{c}\text { Slope at } \\
\text { ambient } \mathrm{CO}_{2}\end{array}$ & $\begin{array}{c}\text { Effect of } \\
\text { elevated } \mathrm{CO}_{2} \\
\text { on centered } \\
\text { intercept }\end{array}$ & $\begin{array}{l}\text { Effect of } \\
\text { elevated } \mathrm{CO}_{2} \\
\text { on slope }\end{array}$ \\
\hline Field & Death Valley annual & 2 & $<0.001$ & $<0.001$ & & & 0.549 & $<0.001$ & & \\
\hline Field & Deciduous tree & 3 & $<0.001$ & $<0.001$ & & & $<0.001$ & $<0.001$ & & \\
\hline Field & Evergreen shrub & 3 & $<0.001$ & 0.976 & & & $<0.001$ & $<0.001$ & & \\
\hline Field & Evergreen tree & 2 & $<0.001$ & $<0.001$ & & & $<0.001$ & $<0.001$ & & \\
\hline Field & Late successional (Bana) & 5 & $<0.001$ & $<0.001$ & & & $<0.001$ & $<0.001$ & & \\
\hline Field & Late successional (Caatinga) & 5 & $<0.001$ & 0.005 & & & $<0.001$ & $<0.001$ & & \\
\hline Field & Late successional (Tierra Firme) & 5 & $<0.001$ & 0.061 & & & $<0.001$ & $<0.001$ & & \\
\hline Field & Old field annual & 4 & $<0.001$ & 0.953 & & & $<0.001$ & 0.367 & & \\
\hline Field & Pioneer & 2 & $<0.001$ & 0.817 & & & 0.021 & 0.722 & & \\
\hline Field & Secondary successional (Tierra Firme) & 5 & $<0.001$ & 0.413 & & & $<0.001$ & 0.368 & & \\
\hline $\mathrm{CO}_{2}$ & Pine & 3 & $<0.001$ & 0.750 & $<0.001$ & 0.869 & $<0.001$ & 0.813 & 0.324 & 0.907 \\
\hline $\mathrm{CO}_{2}$ & Deciduous tree & 7 & $<0.001$ & 0.996 & $<0.001$ & 0.998 & $<0.001$ & $<0.001$ & $<0.001$ & 0.098 \\
\hline Field & All species & 39 & $<0.001$ & $<0.001$ & & & $<0.001$ & $<0.001$ & & \\
\hline $\mathrm{CO}_{2}$ & All species & 10 & $<0.001$ & 0.999 & $<0.001$ & 1.000 & $<0.001$ & $<0.001$ & $<0.001$ & 0.229 \\
\hline
\end{tabular}


Table 3. Averaged regression coefficients for the community and vegetation types that appeared to group well at ambient $\mathrm{CO}_{2}$ on the basis of tests for similarity of coefficients and cluster analyses. $P$ values for heterogeneous coefficients are approximate (denoted by $\approx$ ).

\begin{tabular}{|c|c|c|}
\hline Community or vegetation type & $\begin{array}{l}\text { Centered intercept at ambient } \\
\qquad \mathrm{CO}_{2} \pm \text { s.e. }\end{array}$ & $\begin{array}{l}\text { Slope at ambient } \\
\mathrm{CO}_{2} \pm \text { s.e. }\end{array}$ \\
\hline \multicolumn{3}{|c|}{ Mass based expressions } \\
\hline & $\mu \mathrm{mol} \mathrm{g} \mathrm{g}^{-1} \mathrm{~s}^{-1}$ & $\mu \mathrm{mol} \mathrm{g} \mathrm{g}^{-1} \mathrm{~s}^{-1}$ \\
\hline Late successional Tierra Firme & $0.059 \pm 0.002(P \approx 0.001)$ & $3.741 \pm 0.674(P=0.001)$ \\
\hline Old field annuals & $0.188 \pm 0.026(P \approx 0.001)$ & $6.809 \pm 1.882(P=0.005)$ \\
\hline Amazonian pioneer & $0.161 \pm 0.025(P \approx 0.069)$ & $7.477 \pm 3.366(P=0.196)$ \\
\hline Secondary successional Tierra Firme & $0.121 \pm 0.003(P \approx 0.001)$ & $11.941 \pm 0.692(P=0.001)$ \\
\hline Deciduous trees $\left(\mathrm{CO}_{2}\right.$ experiments) & $0.115 \pm 0.005(P \approx 0.001)$ & $4.604 \pm 1.096(P=0.001)$ \\
\hline Pines $\left(\mathrm{CO}_{2}\right.$ experiments) & $0.093 \pm 0.009(P \approx 0.003)$ & $7.070 \pm 1.891(P=0.023)$ \\
\hline \multicolumn{3}{|c|}{ Area based expressions } \\
\hline & $\mu \mathrm{mol} \mathrm{m} \mathrm{m}^{-2} \mathrm{~s}^{-1}$ & $\mu \mathrm{mol} \mathrm{g} \mathrm{g}^{-1} \mathrm{~s}^{-1}$ \\
\hline Late successional Tierra Firme & $4.451 \pm 0.125(P \approx 0.001)$ & $3.206 \pm 0.285(P \approx 0.001)$ \\
\hline Old field annuals & $12.544 \pm 0.849(P \approx 0.001)$ & $6.946 \pm 1.247(P=0.002)$ \\
\hline Amazonian pioneer & $12.717 \pm 1.234(P \approx 0.044)$ & $5.764 \pm 2.904(P=0.014)$ \\
\hline Secondary successional Tierra Firme & $9.053 \pm 0.343(P \approx 0.001)$ & $8.373 \pm 0.942(P=0.001)$ \\
\hline Deciduous trees ( $\mathrm{CO}_{2}$ experiments) & $7.769 \pm 0.265(P \approx 0.001)$ & $4.644 \pm 0.622(P \approx 0.001)$ \\
\hline Pines $\left(\mathrm{CO}_{2}\right.$ experiments) & $7.285 \pm 0.370(P \approx 0.001)$ & $3.551 \pm 1.198(P=0.036)$ \\
\hline
\end{tabular}


Table 4. Pooled regression coefficients testing the effect of elevated $\mathrm{CO}_{2}$ on the $\mathrm{A}-\mathrm{N}$ relationship for pines and deciduous trees. A Bonferroni-adjusted $P$ value of 0.025 is significant at a family-level confidence of $10 \%$.

\begin{tabular}{|c|c|c|c|c|c|}
\hline Tree type & $R^{2}$ & $\begin{array}{l}\text { Centered intercept at } \\
\text { ambient } \mathrm{CO}_{2} \pm \text { s.e. }\end{array}$ & $\begin{array}{l}\text { Slope at ambient } \\
\qquad \mathrm{CO}_{2} \pm \text { s.e. }\end{array}$ & $\begin{array}{c}\text { Effect of elevated } \mathrm{CO}_{2} \\
\text { on centered } \\
\text { intercept } \pm \text { s.e. }\end{array}$ & $\begin{array}{l}\text { Effect of elevated } \\
\mathrm{CO}_{2} \text { on slope } \pm \text { s.e. }\end{array}$ \\
\hline \multicolumn{6}{|c|}{ Mass based expression } \\
\hline & & $\mu \mathrm{mol} \mathrm{g} \mathrm{g}^{-1} \mathrm{~s}^{-1}$ & $\mu \mathrm{mol} \mathrm{g} \mathrm{g}^{-1} \mathrm{~s}^{-1}$ & $\mu \mathrm{mol} \mathrm{g} \mathrm{g}^{-1} \mathrm{~s}^{-1}$ & $\mu \mathrm{mol} \mathrm{g} \mathrm{g}^{-1} \mathrm{~s}^{-1}$ \\
\hline Pines & 0.990 & $\begin{array}{c}0.110 \pm 0.004 \\
(P=0.001)\end{array}$ & $\begin{array}{c}9.046 \pm 1 \cdot 100 \\
(P=0.014)\end{array}$ & $\begin{array}{c}0.055 \pm 0.007 \\
(P=0.014)\end{array}$ & $\begin{array}{c}1.600 \pm 1.587 \\
(P=0.420)\end{array}$ \\
\hline Deciduous & 0.784 & $\begin{array}{c}0.094 \pm 0.029 \\
(P=0.009)\end{array}$ & $\begin{array}{c}15 \cdot 246 \pm 4.017 \\
(P=0.004)\end{array}$ & $\begin{array}{c}0.075 \pm 0.037 \\
(P=0.066)\end{array}$ & $\begin{array}{c}4.311 \pm 6.028 \\
(P=0.491)\end{array}$ \\
\hline $\begin{array}{c}\text { P value for difference } \\
\text { between pines and } \\
\text { deciduous }\end{array}$ & & 0.648 & 0.385 & 0.904 & 0.390 \\
\hline $\begin{array}{l}\text { Pines } \& \text { deciduous } \\
\text { combined }\end{array}$ & 0.821 & $\begin{array}{c}0.109 \pm 0.015 \\
(P<0.001)\end{array}$ & $\begin{array}{c}13.146 \pm 2.389 \\
(P<0.001)\end{array}$ & $\begin{array}{c}0.069 \pm 0.020 \\
(P=0.003)\end{array}$ & $\begin{array}{c}3.859 \pm 3.656 \\
(P=0.307)\end{array}$ \\
\hline \multicolumn{6}{|c|}{ Area based expression } \\
\hline & & $\mu \mathrm{mol} \mathrm{m} \mathrm{m}^{-2} \mathrm{~s}^{-1}$ & $\mu \mathrm{mol} \mathrm{g} \mathrm{g}^{-1} \mathrm{~s}^{-1}$ & $\mu \mathrm{mol} \mathrm{m} \mathrm{m}^{-2} \mathrm{~s}^{-1}$ & $\mu \mathrm{mol} \mathrm{g} \mathrm{g}^{-1} \mathrm{~s}^{-1}$ \\
\hline Pines & 0.940 & $\begin{array}{c}7.445 \pm 0.613 \\
(P=0.007)\end{array}$ & $\begin{array}{c}4.352 \pm 2.335 \\
(P=0.203)\end{array}$ & $\begin{array}{c}4.704 \pm 1.892 \\
(P=0.131)\end{array}$ & $\begin{array}{c}5.371 \pm 6.866 \\
(P=0.516)\end{array}$ \\
\hline Deciduous & 0.915 & $\begin{array}{c}10.400 \pm 1.044 \\
(P<0.001)\end{array}$ & $\begin{array}{c}12.194 \pm 2.397 \\
(P<0.001)\end{array}$ & $\begin{array}{c}4.773 \pm 1.475 \\
(P=0.009)\end{array}$ & $\begin{array}{c}3.925 \pm 3.073 \\
(P=0.230)\end{array}$ \\
\hline $\begin{array}{c}P \text { value for difference } \\
\text { between pines and } \\
\text { deciduous }\end{array}$ & & 0.146 & 0.265 & 0.711 & 0.826 \\
\hline $\begin{array}{l}\text { Pines \& deciduous } \\
\text { combined }\end{array}$ & 0.912 & $\begin{array}{c}9.974 \pm 0.753 \\
(P<0.001)\end{array}$ & $\begin{array}{c}12.186 \pm 1.923 \\
(P<0.001)\end{array}$ & $\begin{array}{c}4.827 \pm 1.066 \\
(P<0.001)\end{array}$ & $\begin{array}{c}4.278 \pm 2.487 \\
(P=0.105)\end{array}$ \\
\hline
\end{tabular}


Table 5. Averaged regression coefficients testing the effect of elevated $\mathrm{CO}_{2}$ on the A-N relationship for deciduous trees and pines. $P$ values for heterogeneous coefficients are approximate (denoted by $\approx$ ). A Bonferroni-adjusted $P$ value of 0.025 is significant at a family-level confidence of $10 \%$.

\begin{tabular}{|c|c|c|c|c|}
\hline Tree type & $\begin{array}{l}\text { Centered intercept at } \\
\text { ambient } \mathrm{CO}_{2} \text {. Weighted } \\
\text { mean } \pm \text { s.e. of sample }\end{array}$ & $\begin{array}{l}\text { Slope at ambient } \mathrm{CO}_{2} \text {. } \\
\text { Weighted mean } \\
\pm \text { s.e. of sample }\end{array}$ & $\begin{array}{l}\text { Effect of elevated } \mathrm{CO}_{2} \text { on } \\
\text { centered intercept. } \\
\text { Weighted mean } \\
\pm \text { s.e. of sample }\end{array}$ & $\begin{array}{c}\text { Effect of elevated } \mathrm{CO}_{2} \text { on } \\
\text { slope. Weighted mean } \\
\pm \text { s.e. of sample }\end{array}$ \\
\hline \multicolumn{5}{|c|}{ Mass based expression } \\
\hline & $\mu \mathrm{mol} \mathrm{g} g^{-1} \mathrm{~s}^{-1}$ & $\mu \mathrm{mol} \mathrm{g}{ }^{-1} \mathrm{~s}^{-1}$ & $\mu \mathrm{mol} \mathrm{g} \mathrm{g}^{-1} \mathrm{~s}^{-1}$ & $\mu \mathrm{mol} \mathrm{g} \mathrm{g}^{-1} \mathrm{~s}^{-1}$ \\
\hline Pine & $0.093 \pm 0.009(P \approx 0.003)$ & $7.070 \pm 1.891(P=0.023)$ & $0.061 \pm 0.013(P \approx 0.015)$ & $1.327 \pm 2.846(P=0.504)$ \\
\hline Deciduous & $0.115 \pm 0.005(P \approx 0.001)$ & $4.604 \pm 1.096(P<0.001)$ & $0.043 \pm 0.007(P \approx 0.001)$ & $1.898 \pm 1.550(P=0.018)$ \\
\hline $\begin{array}{l}\text { P value for difference } \\
\text { between pines and } \\
\text { deciduous }\end{array}$ & 0.066 & 0.468 & 0.442 & 0.892 \\
\hline $\begin{array}{l}\text { Pines \& deciduous } \\
\text { combined }\end{array}$ & $0.111 \pm 0.004(P \approx 0.001)$ & $5.224 \pm 0.948(P<0.001)$ & $0.047 \pm 0.006(P \approx 0.001)$ & $1.768 \pm 1.361(P=0.003)$ \\
\hline \multicolumn{5}{|c|}{ Area based expression } \\
\hline & $\mu \mathrm{mol} \mathrm{m} \mathrm{m}^{-2} \mathrm{~s}^{-1}$ & $\mu \mathrm{mol} \mathrm{g}{ }^{-1} \mathrm{~s}^{-1}$ & $\mu \mathrm{mol} \mathrm{m} \mathrm{m}^{-2} \mathrm{~s}^{-1}$ & $\mu \mathrm{mol} \mathrm{g} \mathrm{g}^{-1} \mathrm{~s}^{-1}$ \\
\hline Pine & $7.285 \pm 0.370(P \approx 0.001)$ & $3.551 \pm 1.198(P=0.036)$ & $3.323 \pm 0.539(P=0.009)$ & $0.732 \pm 1.656(P=0.524)$ \\
\hline Deciduous & $7.769 \pm 0.268(P \approx 0.001)$ & $4.644 \pm 0.622(P \approx 0.001)$ & $5.154 \pm 0.405(P \approx 0.001)$ & $4.038 \pm 0.901(P \approx 0.001)$ \\
\hline $\begin{array}{c}P \text { value for difference } \\
\text { between pines and } \\
\text { deciduous }\end{array}$ & 0.546 & 0.796 & 0.226 & 0.294 \\
\hline $\begin{array}{l}\text { Pines \& deciduous } \\
\text { combined }\end{array}$ & $7.605 \pm 0.215(P \approx 0.001)$ & $4.412 \pm 0.552(P \approx 0.001)$ & $4.495 \pm 0.324(P \approx 0.001)$ & $3.283 \pm 0.791(P<0.001)$ \\
\hline
\end{tabular}




\section{Figure legends}

Figure 1. A-N relationships at ambient $\mathrm{CO}_{2}$ for all species pooled together and expressed on a mass basis (panel A) and an area basis (panel B). Points are the mean for each community or vegetation type. Error bars have been omitted for clarity. Largest standard errors were 0.002 for $N_{\text {mass }}, 0.03$ for $A_{\text {mass, }}, 0.2$ for $N_{\text {areas }}$ and

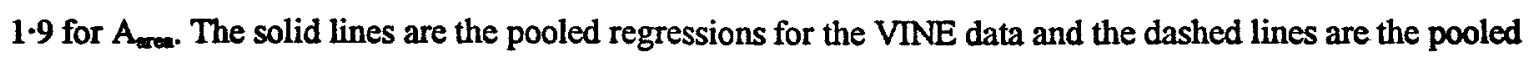
regressions for all ambient $\mathrm{CO}_{2}$ data including the $\mathrm{VINE}$ data and $\mathrm{CO}_{2}$ experiment data. Abbreviations: Amaz $=$ Amazonian; $\mathrm{DC}=$ deciduous chaparral; $\mathrm{DT}=$ deciduous tree; $\mathrm{DV}=$ Death Valley; $\mathrm{EG}=$ Evergreen; $\mathrm{LS}=$ late successional; $\mathrm{MS}=$ mid successional; $\mathrm{OF}=$ old field; $\mathrm{SS}=$ secondary successional.

Figure 2. Intercept vs. slope for the mass-based (panel A) and area-based (panel B) regressions. Points are the coefficients for each species identified by community or vegetation type. Coefficients were standardised to have a mean of zero and standard deviation of one to remove the effects of different scales on the $X$ and $Y$ axes. Abbreviations as for Figure 1.

Figure 3. Pooled regressions for the effect of elevated $\mathrm{CO}_{2}$ on the $\mathrm{A}-\mathrm{N}$ relationship for pines ( $\triangle$ ) and deciduous trees ( $\bullet$ ) expressed on a mass basis (panel A) and on an area basis (panel B). Closed symbols = ambient $\mathrm{CO}_{2}$, open symbols = elevated $\mathrm{CO}_{2}$. Points are the mean for each species at each $\mathrm{CO}_{2}$ concentration. Error bars have been omitted for clarity. Largest standard errors were 0.003 for $N_{\text {mass }}, 0.03$ for $A_{\text {mamo }}, 0.15$ for $\mathrm{N}_{\text {moes }}$ and 1.5 for $A_{\text {aree. }}$ The dashed vertical lines mark the location of the centered intercepts $\left(0.017\right.$ for $N_{\max }$ and 1.305 for $N_{\text {area }}$ ). 
Figure 4. Averaged regressions for the effect of elevated $\mathrm{CO}_{2}$ on the $\mathrm{A}-\mathrm{N}$ relationship for pines (thick lines) and deciduous trees (thin lines) expressed on a mass basis (panel A) and on an area basis (panel B). Closed symbols and solid lines $=$ ambient $\mathrm{CO}_{2}$, open symbols and dashed lines $=$ elevated $\mathrm{CO}_{2}$. Points are the mean for each species. Error bars have been omitted for clarity. Largest standard errors were 0.003 for $\mathrm{N}_{\text {mases }}, 0.03$ for $A_{\text {mases }} 0.15$ for $N_{\text {arcee, }}$ and 1.5 for $A_{\text {arean }}$. Note that the regression lines are the weighted average regressions and were not calculated directly from the points in the figure. The dashed vertical lines mark the location of the centered intercepts $\left(0 \cdot 017\right.$ for $\mathrm{N}_{\text {maxs }}$ and $1 \cdot 305$ for $\left.\mathrm{N}_{\text {areas }}\right)$. 


\section{Figures}

Figure 1
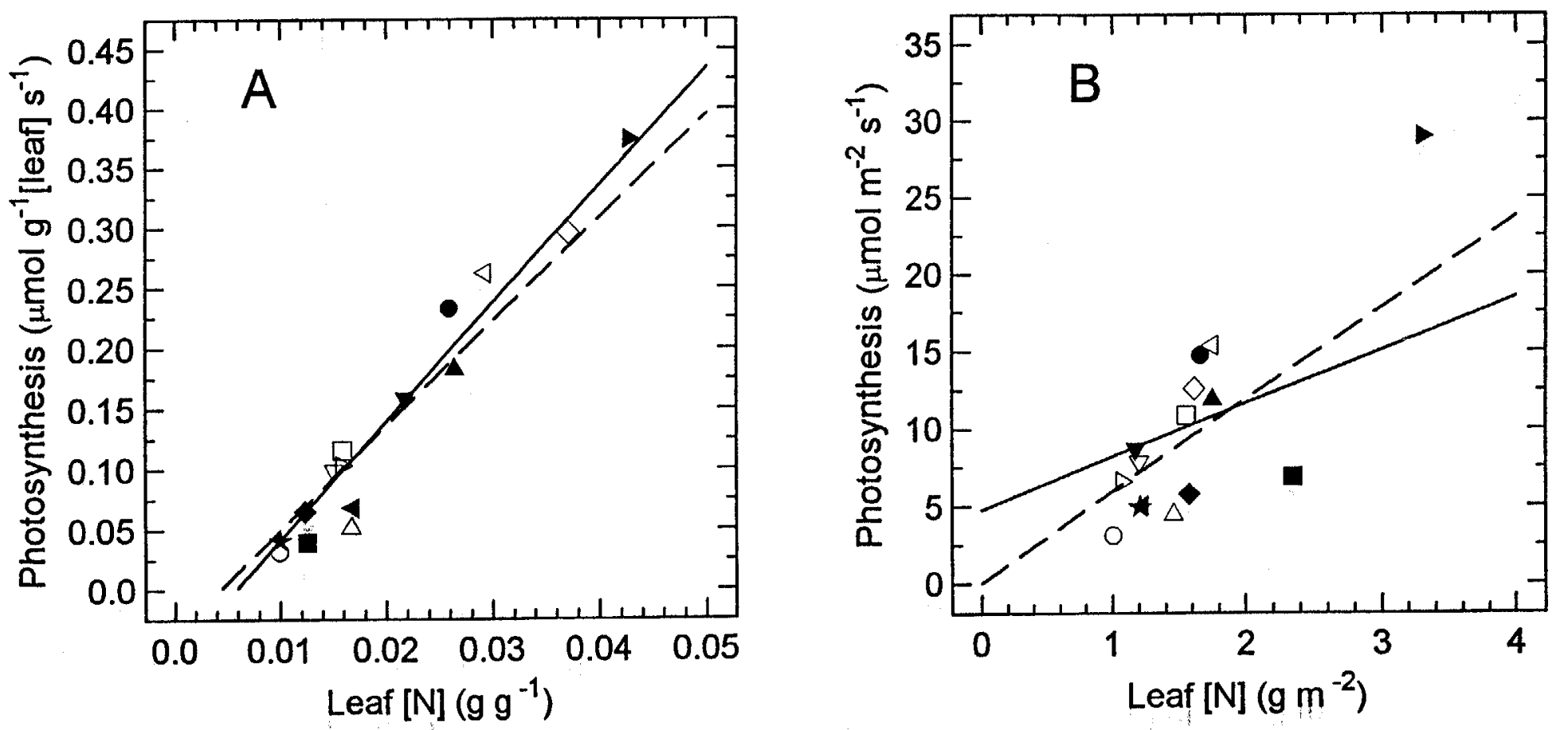

Community or vegetation type
$\diamond$ TropCultivar
$\square$ SS TieraFirm
$\triangle$ Pine $\mathrm{CO} 2$
$\triangleleft$ OF annual
$\nabla$ MS
$\triangle$ LS TieraFirm
- LS Caatinga
$\star$ LS Bana
- EG tree
- EG shrub
- DV annual
$\checkmark$ DT field
$\checkmark$ DT CO2
- DC shrub
- AmazPioneer 


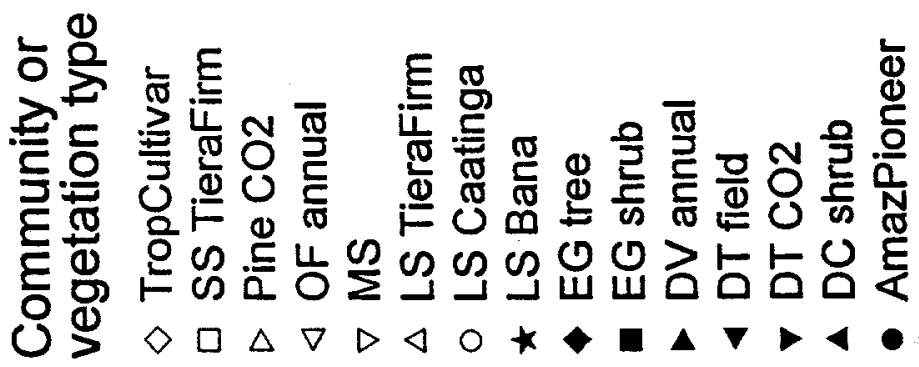

กี
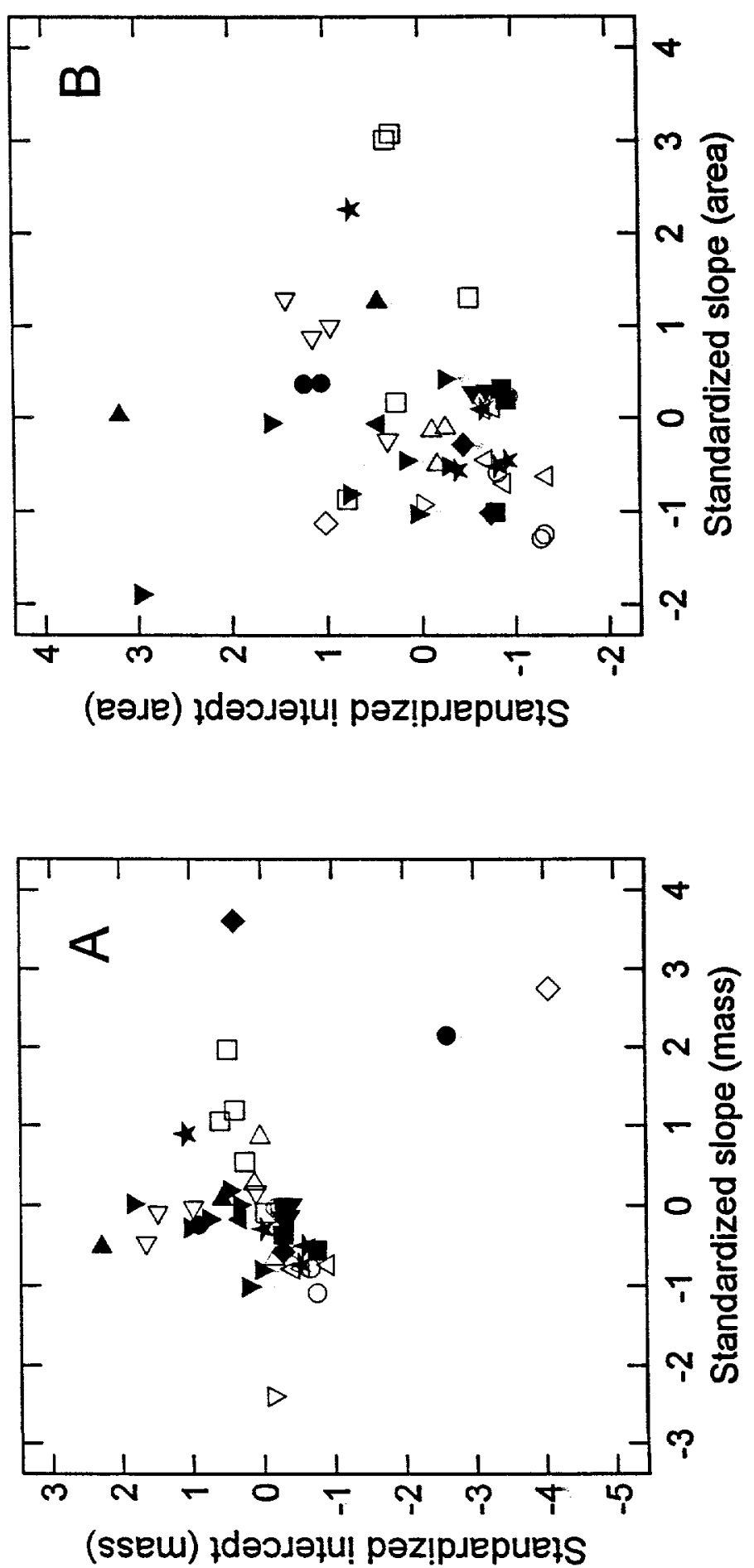

瓷 

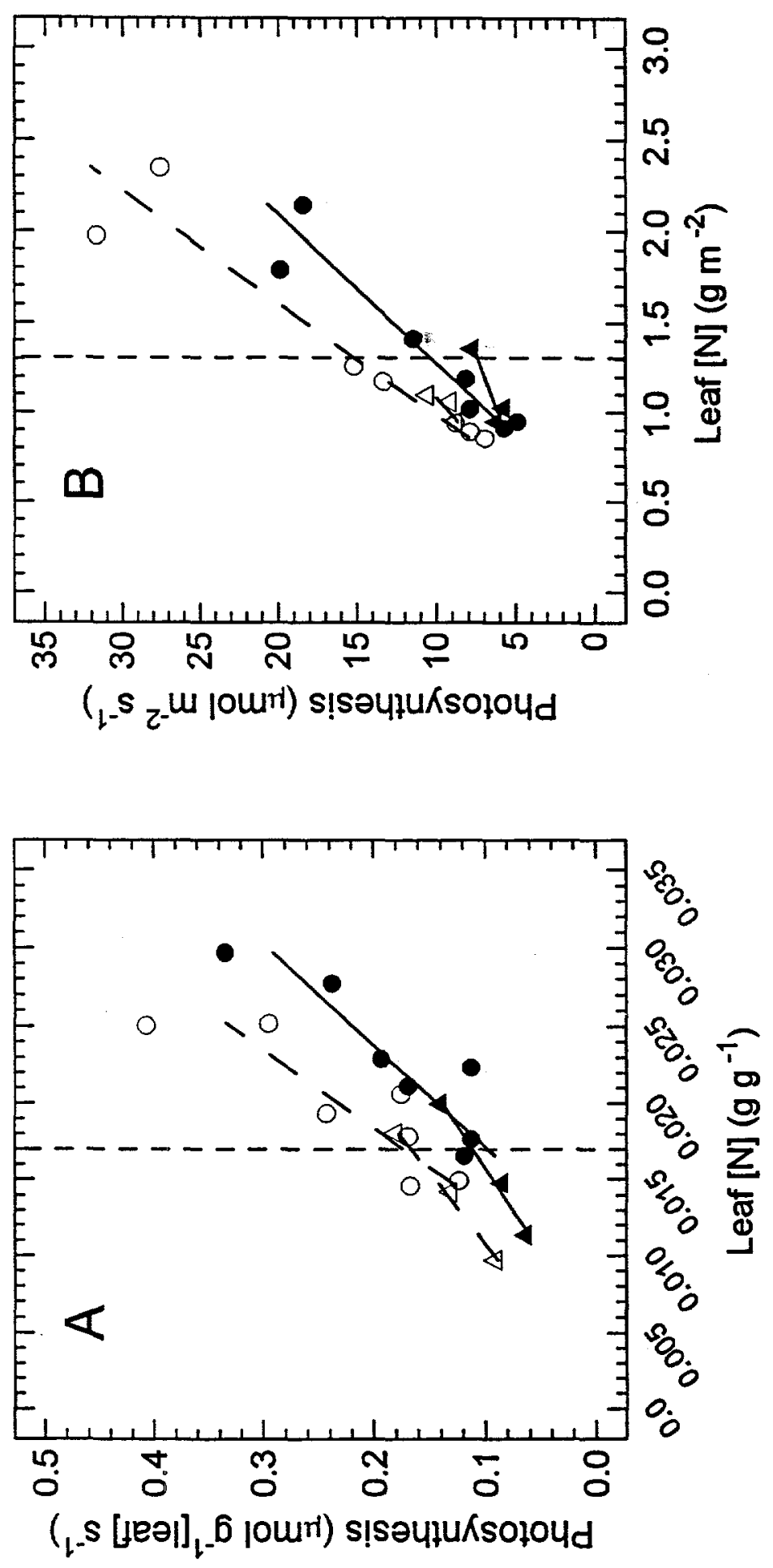

옳 


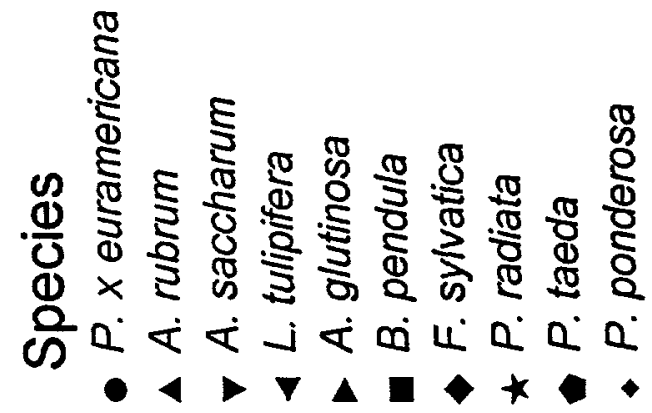

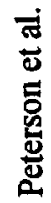

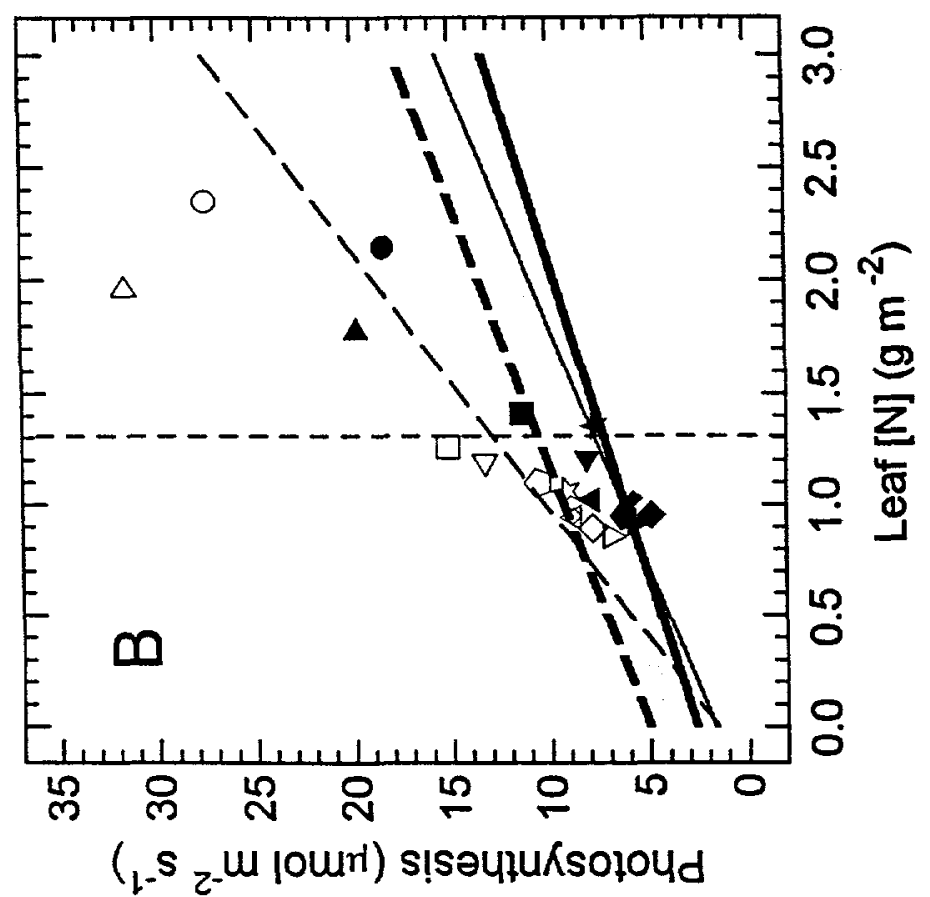

$\frac{\infty}{2}$

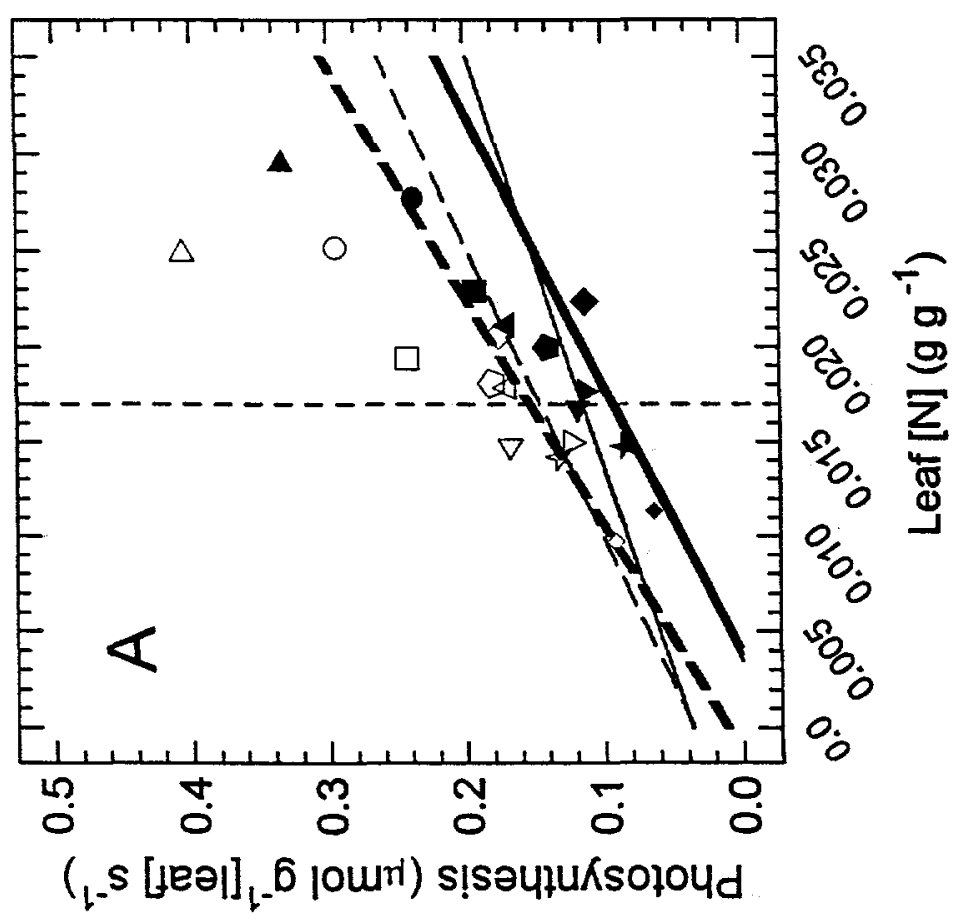


Appendix. Table A1. Results for the mass and area-based regressions for individual species from the field observations. Citations are: $1=$ Field and Mooney (1986); $2=$ Reich $\theta t$ al. (1991b); $3=$ Reich et al. (1994).

\begin{tabular}{|c|c|c|c|c|c|c|c|c|}
\hline \multirow[b]{2}{*}{$\begin{array}{l}\text { Community or } \\
\text { vegetation type and } \\
\text { citation number }\end{array}$} & \multirow[b]{2}{*}{ Species } & \multirow[b]{2}{*}{$\mathbf{N}$} & \multicolumn{3}{|c|}{ Mass based expression } & \multicolumn{3}{|c|}{ Area based expression } \\
\hline & & & $\mathbf{R}^{2}$ & $\begin{array}{l}\text { Centered intercept } \pm \text { s.e. } \\
\text { (P value) } \\
\mu \mathrm{mol} \mathrm{g} \mathrm{s}^{-1} \mathrm{~s}^{-1}\end{array}$ & $\begin{array}{l}\text { Slope } \pm \text { s.e. } \\
\text { (P value) } \\
\mu \mathrm{mol} g^{-1} \mathrm{~s}^{-1}\end{array}$ & $\mathrm{R}^{2}$ & $\begin{array}{l}\text { Centered intercept } \pm \text { s.e. } \\
\text { (P value) } \\
\mu \mathrm{mol} \mathrm{m} \mathrm{m}^{-2} \mathrm{~s}^{-1}\end{array}$ & $\begin{array}{l}\text { Slope } \pm \text { s.e. } \\
\text { (P value) } \\
\mu \mathrm{mol} \mathrm{g} \mathrm{g}^{-1} \mathrm{~s}^{-1}\end{array}$ \\
\hline \multirow[t]{2}{*}{ Death Valley annual 1} & Abronia villosa & 4 & 0.619 & $0.268 \pm 0.062(0.049)$ & $4.609 \pm 2.555(0.213)$ & 0.547 & $21.634 \pm 6.142(0.072)$ & $4.673 \pm 3.007(0.260)$ \\
\hline & Gerea canescens & 7 & 0.916 & $0.139 \pm 0.033(0.009)$ & $8.381 \pm 1.135(0.001)$ & 0.908 & $9.952 \pm 2.646(0.013)$ & $8.815 \pm 1.252(0.001)$ \\
\hline $\begin{array}{c}\text { Deciduous } \\
\text { chaparral shrub } 1\end{array}$ & Lepechinia calycina & 30 & 0.810 & $0.120 \pm 0.008(<0.001)$ & $6.546 \pm 0.600(<0.001)$ & 0.521 & $9.938 \pm 0.479(<0.001)$ & $4.269 \pm 0.773(<0.001)$ \\
\hline \multirow[t]{3}{*}{ Deciduous tree 2} & Acer rubrum & 28 & 0.758 & $0.076 \pm 0.003(<0.001)$ & $6.416 \pm 0.712(<0.001)$ & 0.704 & $5.672 \pm 0.265(<0.001)$ & $5.320 \pm 0.677(<0.001)$ \\
\hline & Acer saccharum & 81 & 0.745 & $0.068 \pm 0.002(<0.001)$ & $6.534 \pm 0.430(<0.001)$ & 0.750 & $5.690 \pm 0.179(<0.001)$ & $5.324 \pm 0.346(<0.001)$ \\
\hline & Quercus ellipsoidalis & 33 & 0.538 & $0.066 \pm 0.005(<0.001)$ & $7.457 \pm 1.240(<0.001)$ & 0.565 & $5.065 \pm 0.696(<0.001)$ & $5.377 \pm 0.847(<0.001)$ \\
\hline \multirow[t]{3}{*}{ Evergreen shrub 1} & Prunus ilicifolia & 10 & 0.647 & $0.039 \pm 0.003(<0.001)$ & $4.110 \pm 1.073(0.005)$ & 0.163 & $4.688 \pm 1.860(0.036)$ & $1.107 \pm 0.887(0.247)$ \\
\hline & Heteromeles arbutifolia & 12 & 0.666 & $0.075 \pm 0.010(<0.001)$ & $5.315 \pm 1.191(0.001)$ & 0.841 & $4.165 \pm 0.530(<0.001)$ & $5.140 \pm 0.708(<0.001)$ \\
\hline & Rhamnus califomica & 6 & 0.865 & $0.073 \pm 0.006(<0.001)$ & $7.461 \pm 1.473(0.007)$ & 0.570 & $4.378 \pm 1.356(0.032)$ & $5.544 \pm 2.408(0.083)$ \\
\hline \multirow[t]{2}{*}{ Evergreen tree 1} & Arbutus menzesll & 13 & 0.704 & $0.075 \pm 0.006(<0.001)$ & $4.021 \pm 0.785(<0.001)$ & 0.682 & $6.137 \pm 0.229(<0.001)$ & $3.531 \pm 0.727(0.001)$ \\
\hline & $\begin{array}{c}\text { Umbellularia } \\
\text { califomica }\end{array}$ & 12 & 0.203 & $0.126 \pm 0.052(0.035)$ & $30.303 \pm 18.998(0.142)$ & 0.079 & $4.892 \pm 1.050(0.001)$ & $1.084 \pm 1.168(0.375)$ \\
\hline \multirow{5}{*}{$\begin{array}{l}\text { Late successional } \\
\text { (Bana) } 3\end{array}$} & Aspidosperma album & 41 & 0.443 & $0.074 \pm 0.008(<0.001)$ & $5.340 \pm 0.958(<0.001)$ & 0.306 & $4.608 \pm 0.192(<0.001)$ & $2.752 \pm 0.663(<0.001)$ \\
\hline & Neea obovata & 31 & 0.362 & $0.052 \pm 0.004(<0.001)$ & $4.457 \pm 1.100(<0.001)$ & 0.346 & $4.139 \pm 0.517(<0.001)$ & $2.962 \pm 0.757(0.001)$ \\
\hline & Protium sp. & 34 & 0.033 & $0.064 \pm 0.004(<0.001)$ & $2.685 \pm 2.550(0.300)$ & 0.325 & $5.092 \pm 0.333(<0.001)$ & $2.991 \pm 0.763(<0.001)$ \\
\hline & $\begin{array}{l}\text { Retiniphyllum } \\
\text { truncatum }\end{array}$ & 37 & 0.566 & $0.178 \pm 0.020(<0.001)$ & $13.246 \pm 1.959(<0.001)$ & 0.423 & $11.145 \pm 1.196(<0.001)$ & $12.005 \pm 2.370(<0.001)$ \\
\hline & $\begin{array}{c}\text { Rhodognaphalopsis } \\
\text { humilis }\end{array}$ & 19 & 0.113 & $0.096 \pm 0.038(0.021)$ & $5.772 \pm 3.932(0.160)$ & 0.049 & $6.413 \pm 0.846(<0.001)$ & $2.611 \pm 2.777(0.360)$ \\
\hline \multirow{5}{*}{$\begin{array}{c}\text { Late successional } \\
\text { (Caatinga) } 3\end{array}$} & Caraipa hoterocarpa & 33 & 0.004 & $0.039 \pm 0.016(0.020)$ & $0.823 \pm 2.373(0.731)$ & 0.677 & $5.213 \pm 0.327(<0.001)$ & $5.221 \pm 0.648(<0.001)$ \\
\hline & Eporua leucantha & 35 & 0.384 & $0.078 \pm 0.006(<0.001)$ & $7.488 \pm 1.649(<0.001)$ & 0.174 & $4.569 \pm 0.327(<0.001)$ & $2.510 \pm 0.953(0.013)$ \\
\hline & Micrandra sprucei & 34 & 0.551 & $0.083 \pm 0.009(<0.001)$ & $7.469 \pm 1.192(<0.001)$ & 0.697 & $4.019 \pm 0.225(<0.001)$ & $5.268 \pm 0.614(<0.001)$ \\
\hline & Micropholis maguirel & 32 & 0.102 & $0.045 \pm 0.014(0.003)$ & $2.783 \pm 1.506(0.075)$ & 0.002 & $2.619 \pm 0.257(<0.001)$ & $0.182 \pm 0.739(0.807)$ \\
\hline & Protlum sp. & 22 & 0.385 & $0.078 \pm 0.015(<0.001)$ & $7.033 \pm 1.989(0.002)$ & 0.002 & $2.438 \pm 0.753(0.004)$ & $0.338 \pm 1.696(0.844)$ \\
\hline
\end{tabular}


Table A1 continued.

\begin{tabular}{|c|c|c|c|c|c|c|c|c|}
\hline \multirow[b]{2}{*}{$\begin{array}{l}\text { Community or } \\
\text { vegetation type and } \\
\text { citation number }\end{array}$} & \multirow[b]{2}{*}{ Species } & \multirow[b]{2}{*}{$N$} & \multicolumn{3}{|c|}{ Mass based expression } & \multicolumn{3}{|c|}{ Area based expression } \\
\hline & & & $\mathrm{R}^{2}$ & $\begin{array}{l}\text { Centered intercept } \pm \text { s.e. } \\
(\mathrm{P} \text { value }) \\
\mu \mathrm{mol} \mathrm{g} \mathrm{g}^{-1} \mathrm{~s}^{-1}\end{array}$ & $\begin{array}{l}\text { Slope } \pm \text { s.e. } \\
(\mathrm{P} \text { value }) \\
\mu \mathrm{mol} \mathrm{g}^{-1} \mathrm{~s}^{-1}\end{array}$ & $\mathrm{R}^{2}$ & 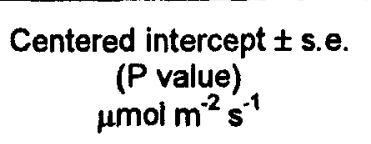 & $\begin{array}{l}\text { Slope } \pm \text { s.e. } \\
\text { (P value) } \\
\mu \mathrm{mol} \mathrm{g}^{-1} \mathrm{~s}^{-1}\end{array}$ \\
\hline \multirow[t]{5}{*}{$\begin{array}{l}\text { Late successional } \\
\text { (Tlerra Firme) } 3\end{array}$} & $\begin{array}{c}\text { "Cabarl" } \\
\text { (Leguminaceae) }\end{array}$ & 38 & 0.123 & $0.027 \pm 0.009(0.003)$ & $2.996 \pm 1.331(0.031)$ & 0.404 & $2.343 \pm 0.405(<0.001)$ & $2.382 \pm 0.482(<0.001)$ \\
\hline & Eperua purpurea & 24 & 0.431 & $0.061 \pm 0.003(<0.001)$ & $4.027 \pm 0.986(<0.001)$ & 0.431 & $5.186 \pm 0.546(<0.001)$ & $4.802 \pm 1.177(0.001)$ \\
\hline & Licania heteromorpha & 35 & 0.196 & $0.070 \pm 0.009(<0.001)$ & $5.708 \pm 2.011(0.008)$ & 0.695 & $4.733 \pm 0.191(<0.001)$ & $4.848 \pm 0.558(<0.001)$ \\
\hline & Ocotea costulata & 29 & 0.055 & $0.055 \pm 0.004(<0.001)$ & $2.768 \pm 2.216(0.222)$ & 0.285 & $4.275 \pm 0.237(<0.001)$ & $2.142 \pm 0.653(0.003)$ \\
\hline & Protium sp. & 22 & 0.084 & $0.057 \pm 0.019(0.007)$ & $3.008 \pm 2.217(0.190)$ & 0.196 & $5.242 \pm 0.768(<0.001)$ & $4.819 \pm 2.184(0.039)$ \\
\hline Mid successional 3 & Goupia glabra & 21 & 0.348 & $0.086 \pm 0.006(<0.001)$ & $.7 .419 \pm 2.330(0.005)$ & 0.041 & $7.987 \pm 0.416(<0.001)$ & $1.395 \pm 1.545(0.378)$ \\
\hline \multirow[t]{4}{*}{ Old field annual 1} & Abutilon theophrasti & 4 & 0.477 & $0.103 \pm 0.074(0.297)$ & $8.427 \pm 6.242(0.309)$ & 0.437 & $9.529 \pm 2.917(0.082)$ & $3.582 \pm 2.874(0.339)$ \\
\hline & Ambrosia trifida & 4 & 0.704 & $0.208 \pm 0.041(0.036)$ & $6.825 \pm 3.129(0.161)$ & 0.690 & $14.079 \pm 2.712(0.035)$ & $8.691 \pm 4.115(0.169)$ \\
\hline & Chenopodium album & 5 & 0.668 & $0.170 \pm 0.054(0.052)$ & $7.230 \pm 2.944(0.091)$ & 0.871 & $12.069 \pm 1.805(0.007)$ & $7.709 \pm 1.713(0.020)$ \\
\hline & $\begin{array}{c}\text { Polygonum } \\
\text { pensylvanicum }\end{array}$ & 8 & 0.114 & $0.220 \pm 0.056(0.008)$ & $4.454 \pm 5.066(0.413)$ & 0.522 & $12.896 \pm 1.100(<0.001)$ & $7.309 \pm 2.857(0.043)$ \\
\hline Amazonlan pioneer 3 & Solanum straminifolia & 6 & 0.467 & $-0.100 \pm 0.253(0.714)$ & $21 \cdot 124 \pm 11.283(0.134)$ & 0.115 & $13.279 \pm 2.285(0.004)$ & $5.728 \pm 7.958(0.512)$ \\
\hline Pioneer (Tierra Firme) 3 & Cecropla ficifolia & 27 & 0.108 & $0.164 \pm 0.025(<0.001)$ & $6.144 \pm 3.527(0.094)$ & 0.120 & $12.486 \pm 1.466(<0.001)$ & $5.770 \pm 3.119(0.076)$ \\
\hline \multirow[t]{5}{*}{$\begin{array}{l}\text { Secondary successional } \\
\text { (Tlerra Firme) } 3\end{array}$} & $\begin{array}{l}\text { Bellucia } \\
\text { grossularioides }\end{array}$ & 18 & 0.817 & $0.115 \pm 0.006(<0.001)$ & $11.081 \pm 1.311(<0.001)$ & 0.354 & $9.139 \pm 1.446(<0.001)$ & $5.051 \pm 1.707(0.009)$ \\
\hline & Clidemia sericea & 18 & 0.803 & $0.125 \pm 0.006(<0.001)$ & $15.121 \pm 1.875(<0.001)$ & 0.740 & $9.551 \pm 0.548(<0.001)$ & $14.515 \pm 2.150(<0.001)$ \\
\hline & Miconia dispar & 12 & 0.770 & $0.093 \pm 0.006(<0.001)$ & $7.070 \pm 1.223(<0.001)$ & 0.656 & $5.814 \pm 0.796(<0.001)$ & $8.856 \pm 2.026(0.001)$ \\
\hline & Vismia japurensis & 34 & 0.639 & $0.141 \pm 0.007(<0.001)$ & $14.239 \pm 1.892(<0.001)$ & 0.014 & $11.357 \pm 0.879(<0.001)$ & $1.584 \pm 2.359(0.507)$ \\
\hline & Vismia lauriformis & 22 & 0.846 & $0.132 \pm 0.005(<0.001)$ & $19.969 \pm 1.905(<0.001)$ & 0.609 & $9.288 \pm 0.737(<0.001)$ & $14.732 \pm 2.638(<0.001)$ \\
\hline Tropical cultivar 3 & Manihot esculenta & 14 & 0.451 & $-0.209 \pm 0.163(0.223)$ & $24.860 \pm 7.920(0.009)$ & 0.001 & $12.336 \pm 2.455(<0.001)$ & $0.720 \pm 7.029(0.920)$ \\
\hline
\end{tabular}


Table A2. Results for the mass and area-based regressions for individual species from the $\mathrm{CO}_{2}$ experiments. Citations are: $1=$ Norby et al. $(1997) ; 2=\mathrm{Vogel}$ and $\mathrm{Curtis}(1995) ; 3=$ Rey and Jarvis (1998); 4 = Forstreuter (1995); $5=$ Gunderson and Wullschleger (1994); $6=$ Curtis ot al. (1995); $7=$ Tissue ot al. (in review); $8=$ Whitehead ot al. (1995); $9=$ Tissue et al. (1997).

\begin{tabular}{|c|c|c|c|c|c|c|c|c|}
\hline $\begin{array}{l}\text { Tree type and } \\
\text { citatlon number }\end{array}$ & Species & N & $R^{2}$ & $\begin{array}{l}\text { Centered intercept at } \\
\text { ambient } \mathrm{CO}_{2} \\
\pm \text { s.e. ( } \mathrm{P} \text { value) }\end{array}$ & $\begin{array}{c}\text { Slope at ambient } \mathrm{CO}_{2} \\
\pm \text { s.e. ( } \mathrm{P} \text { value) }\end{array}$ & $\begin{array}{l}\text { Effect of elevated } \mathrm{CO}_{2} \text { on } \\
\text { centered intercept } \pm \text { s.e. (P } \\
\text { value) }\end{array}$ & $\begin{array}{l}\text { Effect of elevated } \mathrm{CO}_{2} \text { on } \\
\text { slope } \pm \text { s.e. ( } \mathrm{P} \text { value) }\end{array}$ & $\begin{array}{c}\text { ANOVA P } \\
\text { value }\end{array}$ \\
\hline \multicolumn{9}{|c|}{ Mass based expression } \\
\hline & & & & $\mu \mathrm{mol} \mathrm{g}^{-1} \mathrm{~s}^{-1}$ & $\mu \mathrm{mol} \mathrm{g}{ }^{-1} \mathrm{~s}^{-1}$ & $\mu \mathrm{mol} \mathrm{g} \mathrm{g}^{-1} \mathrm{~s}^{-1}$ & $\mu \mathrm{mol} \mathrm{g}^{-1} \mathrm{~s}^{-1}$ & \\
\hline \multirow{2}{*}{$\begin{array}{c}\text { Deciduous } 1 \\
1\end{array}$} & Acer nubrum & 69 & 0.333 & $0.131 \pm 0.018(<0.001)$ & $8.796 \pm 3.201(0.008)$ & $0.018 \pm 0.022(0.416)$ & $10.190 \pm 4.969(0.044)$ & $<0.001$ \\
\hline & Acer saccharum & 72 & 0.109 & $0.111 \pm 0.007(<0.001)$ & $1.252 \pm 2.966(0.674)$ & $0.027 \pm 0.012(0.021)$ & $7.047 \pm 4.344(0.109)$ & 0.048 \\
\hline 2 & Alnus glutinosa & 23 & 0.309 & $0.234 \pm 0.091(0.018)$ & $7.740 \pm 6.808(0.270)$ & $0.021 \pm 0.137(0.877)$ & $10.593 \pm 13.878(0.455)$ & 0.066 \\
\hline 3 & Betula pendula & 45 & 0.370 & $0.153 \pm 0.030(<0.001)$ & $6.552 \pm 3.920(0.102)$ & $0.048 \pm 0.035(0.178)$ & $8.411 \pm 5.504(0.095)$ & $<0.001$ \\
\hline 4 & Fagus syivatica & 87 & 0.468 & $0.098 \pm 0.011(<0.001)$ & $2.595 \pm 1.793(0.152)$ & $0.065 \pm 0.015(<0.001)$ & $0.704 \pm 2.668(0.793)$ & $<0.001$ \\
\hline 5 & Liriodendron tulipifera & 23 & 0.516 & $0.120 \pm 0.009(<0.001)$ & $7.646 \pm 3.792(0.058)$ & $0.051 \pm 0.013(0.001)$ & $.5 .786 \pm 4.471(0.211)$ & 0.003 \\
\hline 6 & Populus euramericana & 29 & 0.372 & $0.174 \pm 0.033(<0.001)$ & $5.835 \pm 2.542(0.030)$ & $0.087 \pm 0.041(0.041)$ & $-1.814 \pm 3.259(0.583)$ & 0.008 \\
\hline Pine 7 & Pinus ponderosa & 27 & 0.642 & $0.084 \pm 0.014(<0.001)$ & $3.718 \pm 2.380(0.132)$ & $0.081 \pm 0.028(0.008)$ & $6.702 \pm 4.127(0.118)$ & $<0.001$ \\
\hline 8 & Pinus radiata & 33 & 0.352 & $0.105 \pm 0.020(<0.001)$ & $9.576 \pm 8.765(0.284)$ & $0.019 \pm 0.026(0.471)$ & $12.507 \pm 10.255(0.232)$ & 0.005 \\
\hline 9 & Pinus taeda & 42 & 0.442 & $0.099 \pm 0.015(<0.001)$ & $13.267 \pm 3.329(<0.001)$ & $0.073 \pm 0.018(<0.001)$ & $-6.310 \pm 4.255(0.146)$ & $<0.001$ \\
\hline \multicolumn{9}{|c|}{ Area based expression } \\
\hline & & & & $\mu \mathrm{mol} \mathrm{m} \mathrm{m}^{-2} \mathrm{~s}^{-1}$ & $\mu \mathrm{mol} \mathrm{g} \mathrm{g}^{-1} \mathrm{~s}^{-1}$ & $\mu \mathrm{mol} \mathrm{m} \mathrm{m}^{-2} \mathrm{~s}^{-1}$ & $\mu \mathrm{mol} \mathrm{g} \mathrm{g}^{-1} \mathrm{~s}^{-4}$ & \\
\hline \multirow{2}{*}{$\begin{array}{c}\text { Deciduous } 1 \\
1\end{array}$} & Acer rubrum & 69 & 0.201 & $8.724 \pm 0.908(<0.001)$ & $2.960 \pm 2.458(0.233)$ & $6.221 \pm 1.986(0.003)$ & $14.019 \pm 5.199(0.009)$ & 0.002 \\
\hline & Acer saccharum & 72 & 0.215 & $6.810 \pm 0.763(<0.001)$ & $2.772 \pm 1.694(0.107)$ & $2.725 \pm 1.164(0.022)$ & $3.076 \pm 2.460(0.215)$ & 0.001 \\
\hline 2 & Alnus glutinosa & 23 & 0.683 & $20.715 \pm 3.222(<0.001)$ & $-1.830 \pm 6.039(0.765)$ & $11.510 \pm 5.182(0.039)$ & $0.969 \pm 8.347(0.909)$ & $<0.001$ \\
\hline 3 & Betula pendula & 45 & 0.299 & $11.253 \pm 0.930(<0.001)$ & $1.763 \pm 2.699(0.517)$ & $4.223 \pm 1.275(0.002)$ & $4.532 \pm 3.506(0.203)$ & 0.002 \\
\hline 4 & Fagus sylvatica & 87 & 0.787 & $6.971 \pm 0.349(<0.001)$ & $5.902 \pm 0.779(<0.001)$ & $5.332 \pm 0.545(<0.001)$ & $4.881 \pm 1.159(<0.001)$ & $<0.001$ \\
\hline 5 & Liriodendron tulipifera & 23 & 0.684 & $8.249 \pm 0.754(<0.001)$ & $1.059 \pm 2.600(0.688)$ & $5.684 \pm 0.989(<0.001)$ & $3.697 \pm 3.033(0.238)$ & $<0.001$ \\
\hline 6 & Populus euramericana & 29 & 0.574 & $14.787 \pm 2.792(<0.001)$ & $4.310 \pm 2.985(0.161)$ & $14.277 \pm 3.565(<0.001)$ & $5.778 \pm 3.509(0.112)$ & $<0.001$ \\
\hline \multirow{3}{*}{$\begin{array}{c}\text { Pine } 7 \\
8\end{array}$} & Pinus ponderosa & 27 & 0.743 & $6.940 \pm 0.630(<0.001)$ & $4.234 \pm 1.938(0.039)$ & $4.538 \pm 0.967(<0.001)$ & $3.183 \pm 2.685(0.248)$ & $<0.001$ \\
\hline & Pinus radiata & 33 & 0.168 & $7.548 \pm 0.564(<0.001)$ & $4.140 \pm 3.702(0.273)$ & $1.987 \pm 0.854(0.027)$ & $-2.576 \pm 4.070(0.532)$ & 0.142 \\
\hline & Pinus taeda & 42 & 0.528 & $7.314 \pm 0.780(<0.001)$ & $2.922 \pm 1.672(0.089)$ & $3.862 \pm 1.001(<0.001)$ & $-0.117 \pm 2.459(0.962)$ & $<0.001$ \\
\hline
\end{tabular}

